i staleśmy dotrwali" ${ }^{32}$. Do córki zaś pisał „tym listem napomniany, aby T. M. nikomu gwoli myśli swej, przeciwko wierze świętej nie odmieniała, jedno tak mocne i stale w tem trwała, jako T. $M$. $\mathrm{z}$ młodości jest nauczona i wychowana" ${ }^{33}$. Zdarzało się również, że sprzyjały one po latach różnowiercom, jak Zofia, czy Katarzyna Jagiellonka Maksymilian Emanuel zarzucał swojej żonie właśnie brak pobożności, a szczególnie jej publicznych przejawów. Według tego co pisał do Marysieński Sobieskiej dla jej córki ważniejsze były bale, na których bawiła się całe noce i dlatego nie miała sił rankiem iść do kościoła ${ }^{34}$.

Następnym elementem była nauka języków. Uczyły się nasze królewny łaciny - znały ten język m.in. Elżbieta Lokietkówna, Jadwiga córka Kazimierza Jagiellończyka i Rakuszanki, córki Zygmunta Starego, wreszcie Teresa Kunegunda Sobieska; włoskiego - córki Bony; francuskiego - Teresa Kunegunda, niemieckiego - Jadwiga córka Elżbiety Rakuszanki, córki Bony. Nie znała tego języka Jadwiga margrabina brandenburska. Kiedy wyjeżdżała do męża jej ojciec król Zygmunt pełen troski o córkę prosiłł, „by małżonka jego mogła trzymać przy sobie ludzi obojej płci z ziomków swoich mówiących jej językiem, dopóki się sama niemieckiego języka nie nauczy" ${ }^{35}$, minęło kilka lat zanim opanowała ten język.

Niekiedy wynosiły $\mathrm{z}$ rodzinnego dworu zamiłowanie do lektury, świadczą o tym ich księgozbiory (córki Bony).

Obok tego zdobywały zapewne królewny umiejętności „czysto” kobiece - tkanie, wyszywanie itp; wiadomo, że uczyły się tego córki Bony.

Wychowanie córek władców polskich nie odbiegało od ogólnie przyjętych kobiecych wzorców edukacyjnych. Uzupełnione bywało nielicznymi elementami, takimi jak nauka języków obcych, ale niekiedy było to po prostu spowodowane pochodzeniem $\mathrm{i}$ językiem narodowym matki, która, rzecz zrozumiała, uczyła córki swej ojczystej mowy. Tak jak nie przywiązywano wagi do kształcenia dziewcząt, tak i w przypadku córek królewskich i książęcych ten element edukacji nie zawsze był doceniany. Starannie natomiast wychowywano dziewczęta pod względem religijnym i moralnym.

Artur Kijas

Poznań

\title{
Uczeni wileńscy na Uniwersytecie Charkowskim w pierwszej polowie XIX wieku
}

Uniwersytet Charkowski, którego współzałożycielem i dobroczyńcą był Polak Seweryn Potocki, w swojej bogatej historii odnotował polskie nazwiska. Polacy byli zarówno profesorami, jak i studentami tego uniwersytetu. W pierwszym półwieczu jego istnienia dość liczną kategorię wśród profesorów i wykładowców stanowili uczeni wileńscy.

\footnotetext{
${ }^{32}$ A. Przeździecki, Jagiellonki polskie..., s. 88.

${ }^{33}$ A. Przeździecki, Jagiellonki polskie..., s. 88.

${ }^{34}$ M. Komaszyński, Teresa Kunegunda..., s. 66

35 A. Przeźdriecki, Jagiellonki polskie..., s. 82.
} 
Listę znakomitych profesorów, którzy na jakiś czas bądź na zawsze związali się z Charkowem, otwiera Ignacy Daniłowicz. ${ }^{1}$. Na Uniwersytecie Wileńskim zajmował się on głównie prawem litewskim oraz dziejami Wielkiego Księstwa. Wydalony z Wilna, dzięki zaangażowaniu Iwana Łobojki, który interweniował u ministra wyznań religijnych i oświaty Aleksandra Szyszkowa, trafił do Charkowa $z$ roczną pensją 2 tys. rubli ${ }^{2}$. Władimir Francew cytuje fragment listu Daniłowicza do Lelewela z 28 stycznia 1825 r., w którym ten ostatni zawiadamiał: „Niewyczerpana dobroć Najłaskawszego Monarchy zaleciła Ministrowi danie mi miejsca w Imperium i już jestem profesorem Dyplomacji lub Dyplomatyki w Charkowie, gdzie za kilka dni przez Moskwę, Tułę i Oreł wybieram się"' $\mathrm{Z}$ materiałów źródłowych wynika więc, że nominację otrzymał na profesora dyplomatyki w Katedrze Dyplomatyki i Ekonomii Politycznej ${ }^{\dagger}$. Dopiero w następstwie interwencji u rektora i w Radzie Uniwersyteckiej powierzono mu Katedrę Prawa Rosyjskiego i Prowincjonalnego, obejmującego także przyłączone do Rosji ziemie polskie ${ }^{5}$. Był to obszar, na którym do 1840 r. obowiązywal Statut litewski 1588 roku.

Charków zrobił na Daniłowiczu nie najlepsze wrażenie ${ }^{6}$. Wiosenne roztopy spowodowały, że wkrótce po jego przybyciu miasto tonęło w błocie. W liście do Lelewela z 5 marca 1825 r. pisat: „Błotniste miasto tak dalece żadnych wygód nie dostarcza, że każdy żenić się musi albo być okradanym przez kucharke, lokaja i furmana"? Brak kwater skarbowych powodował ponadto, że życie przybysza narażone było na inne niewygody, jak choćby te związane $z$ umeblowaniem i prowadzeniem własnego gospodarstwa. Zamieszkał na stancji za rzeką Lopanią, w domu dziekana Wydziału Fizyczno-Matematycznego, Wasyla Komliszyńskiego ${ }^{8}$. Znaczne odległości, nieregularna poczta oddalały nieco Daniłowicza od przyjaciół i ośrodków naukowych, z którymi, będąc w Wilnie, utrzymywał żywe kontakty. W liście z 6 czerwca 1825 r. usprawiedliwiał się: ,(...) obróć proszę wszystką swą żółć na nieregularne poczty, bom ja w tem nie winien"».

Nieocenionym źródłem informacji o pobycie Daniłowicza w Charkowie sq̨ jego listy pisane do przyjaciół z czasów wileńskich, w których donosil o swoich planach naukowych, miejscowym uniwersytecie i jego profesorach, stanie oświaty w Charkowskim Okręgu Naukowym, a także o osobliwościach uniwersyteckiej biblioteki i gabinetu numizmatycznego. Ranga wileńskiego

I. Turkowski, Danilowicz Ignacy, w: PSB, t. IV, Kraków 1938, s. 412-414; A. Cerkas, Danilovic Ignatij, w: Russkij biograficeskij slovar', t. 6, Petersburg 1905, s. 72-76; D. Bagalej, N. Sumcov, V. Buzeskul, Kratkij ocerk istorii Char'kovskogo universiteta za pervye sto let (1805-1905), Char'kov 1906, s. 70-71; B. S. Popkov, DaniloviC.. Ignatij Nikolaevic, w: Slavjanovedenie v dorevoljucionnoj Rossii, op. cit., s. 142 . W biogramie autor pisze, że profesorem Uniwersytetu Charkowskiego był on w latach 1825 - 1835, co jest zgodoe z rzeczywistością gdyż po przejściu do Petersburga zacbował ten tytuł. Patrz także: V. S. Ikonnikov, Biograficeskij slovar' professorov i prepodavatelej Imperatorskogo Universiteta Sv. Vadimira, Kiev 1884, s. 174 - 175 (obszerny i w miare doktadny biogram); Bibliografia literatury polskiej „Nowy Korbut”, t. 4: Oświecenie, Warszawa 1966, s. 406-409; J. Bieliński, Uniwersytet Wilenski (1579-1831), t. III Kraków 1900, s. 153-156; R. W. Wołoszyński, Polsko-rosyjskie zwiqzki w naukach spolecznych, Warszawa 1974, s. 323-325.

${ }^{2}$ Wtadimir Kozłow uważa, że na uniwersytecie w Charkowie znalazł się on w wyniku interwencji Nikołaja Rumiancewa. Patrz: V. P. Kozlov, Kolumby rossijskich drevnostej, Moskva 1981, s. 33; V. A. Francev, Pol'skoe slavjanovedenie konca XVII i pervoj cetverti XIX st., Praga 1906, Prilozienija, s. LXXIX.

${ }^{3}$ Tamie, s. LXXIX (odsylacz).

4 Biblioteka PAN w Krakowie, rkps. 1266, k. 46.

s Tamże, k. 47: list do Lelewela z 6 VI 1825 r. Joanna Kuryło-Omelianiuk pisze, że usuniety z Wilna przeniósł sie "(...) do Uniwersytetu Charkowskiego na katedrę dyplomacji”, co jest nieścisłością. Patrz: J. Kurylo-Omelianiuk, Profesorowie Uniwersytetu Wilenskiego w latach 1803-1832, Bialystok 1993, s. 28.

6 Najtrudniejsze dla Danikowicza byly pierwsze miesiące pobytu w Charkowie. Znajduje to także odbicie w korespondencji Józefa Sękowskiego z Lelewelem. W liście z 1 (13) VII 1825 r. czytamy: „List od Danily z Charkowa tu przyłączam; skarży się on, że mu nie odpisujesz". Natomiast w liście z 11 (23) VIII tegoż roku Sẹkowski ponownie o tym pisze: „Posylam ci list Daniłowicza, który sį̣ skarży, że mu nie odpisujesz, na Boga, bo on do rozpaczy przychodzi i przeszlij list na moje ręœ". Patrz A. Jabłonowski, Orientalista Sękowski w korespondencji z Lelewelem. Studium na tle listów orientalisty osnute, w: A. Jabłonowski, Pisma, t. VII: Rzeczy polskie, Warszawa 1913, s. 126, 129.

'Biblioteka PAN, rkps. 1266, k. 48.

${ }^{8}$ Tamże, k. 48 v.

- Tamże, k. 47. 
uczonego była w Charkowie wysoka. W 1826 r. w Wilnie, przy finansowej pomocy Tytusa Działyńskiego, wydany został Statut Kazimierza Jagiellończyka 1468 roku ${ }^{10}$ (odnaleziony w bibliotece Nikołaja Rumiancewa w Moskwie), w rok później zaś Latopisec Litwy i Kronika ruska, wcześniej drukowany w "Dzienniku Wileńskim" ". Wynikiem numizmatycznych zainteresowan Danilowicza było sporządzenie katalogu medali i monet uniwersyteckiego gabinetu numizmatycznego, w którym zebrane zostały unikalne kolekcje: jedna podarowana uniwersytetowi przez Seweryna Potockiego, druga pochodząca ze zbioru książąt Radziwiłłów z Nieświeża, zrabowana przez armię Pawła Cziczagowa w czasie wojny $1812-1813$ r, a następnie przekazana w darze uniwersytetowi. Ksiądz prof. Bobrowski w liście do Lelewela z 15 maja 1826 r. informowat. "Daniłowicz pisał do mnie z Charkowa, że zdrów, ale nie zupełnie kontent ze swego położenia, chlubił się laskawemi względami tamecznego kuratora, który nawet przyjąl na siebie odpowiedzialność za jego lekcje i wlożył obowiązek opisania numizmatyki, będącej przy Charkowskim Uniwersytecie"12. Z 5782 opisanych przez Daniłowicza medali i monet, 3500 (60,5\%) było polskiego i litewskiego pochodzenia. Pokłosiem numizmatycznych pasji Daniłowicza, rozbudzonych dopiero w Charkowie, był również artykuł w "Tygodniku Petersburskim" $O$ medalach radziwillowskich $i$ o gabinecie nieświeżskim $i$ charkowskim do dzisiaj cytowany, i to nie tylko ze względów bibliograficznych ${ }^{13}$.

Wykłady z rosyjskiego prawa cywilnego i sądownictwa prowadził Daniłowicz według podręcznika Władimira Wieliaminowa-Ziernowa, uzupełnionego własnymi notatkami objaśniajacymi odrębności ustaw w przyłączonych do Rosji guberniach i ziemiach. Prawo karne wykładał natomiast według wlasnych notatek ${ }^{14}$. Zajęcia $w$ uniwersytecie nie były zbyt absorbujące, pochłaniały zaledwie cztery godziny tygodniowo ${ }^{15}$. Czas wolny, poza kontynuacja prac rozpoczętych w Wilnie, przeznaczał na lektury „(...) dorywcze prace nad Dyplomatykq Magnickiego", tłumaczenie na język rosyjski Statutów wiślickich oraz doskonalenie języka rosyjskiego, w którym - jak pisał - „(...) zdaniem miejscowych chachłow (Małorusinów - przyp. A. K.) był nawet mocny" ${ }^{16}$. Miarą popularności Daniłowicza w Charkowie może być fakt, że dwukrotnie wybierano go na dziekana Wydziału Nauk Moralno-Politycznych" ${ }^{17}$. Mimo krytycznych opinii o wielu

${ }^{10}$ Statut Kazimierza Jagielloniczyka, pomnik najdawniejszych uchwal litewskich z XV wieku, wynaleziony i drukiem ogloszony, staraniem Ignacego Danilowicza, profesora w Cesarskim Uniwersytecie Charkowskim, Wilno 1826. Patrz: R. W. Wołoszyński, Polsko-rosyjskie zwiqzki w naukach spolecznych $1801-1830$, op. cit . s. 423 i n. Już na początku pobytu w Charkowie do „Dziennika Warszawskiego" wyslal on artykuł Wiadomości o dziele K. Kalydowicza [winno być Kałajdowicza - przyp. A. K.] i P. Strojewa opisujacem rekopisma slowiańskie i ruskie w bibliotece hr Tolstowa w Moskwie, w: „Driennik Warszawski” 1825, t. II, nr 7 (grudzień), s. 367-391. Na końcu artykutu znalazta sie notka: „Pisatem w Charkowie d. 15 czerwca $1825^{\prime}$.

"Latopisec Litwy i kronika ruska, z rekopismu slawińskiego przepisane, z Wremiennika Sofijskiego pomnożone, prypisami i objaśnieniami dla czytelników polskich potrzebnemi opatrzone, staraniem i pracą Ignacego Danilowicza, profesora zwyczajnego w Cesarskim Uniwersytecie Charkowskim, naprzód w "Dzienniku Wileńskim" r. (1823 i) 1824 czéściami ogłoszone, a teraz w jedno zebrane, dokończone i przedrukowane, Wilno 1827, nakład i druk Antoniego Marcinowskiego. O okolicznościach odnalezienia i wydania Latopisu patrz: N. N. Ulašcik, Vuedenie v izuCenie belorusko-litovskogo letopisanija, Moskva 1985, s. 34-39, 42-45.

12 V. A. Francev, Pol'skoe slavjanovedenie, op. cit, Prilozenija, s. LXXXIII. Kuratorem Charkowskiego Okręgu Naukowego, o którym mowa w liście, był Aleksiej Perowski.

${ }_{13}$ „Tygodnik Petersburski” 1830, nr 38, 24 IX, s. 310-312; nr 40, 8 X, s. 330-333; nr 41, 15 X, s. 342. Artykuł ten wyszedł także jako zwarty druk. $O$ zainteresowaniach i pracach numizmatycznych Daniłowicza patrz także: Biblioteka PAN, rkps. 1266, k. 56-57, 72 i n., 79 i n. Bobrowskiego prosil Danilowicz o „(..) instrukcje do czytania kufickich napisów na pieniądzach". Patrz: V. A. Francev, Pol'skoe slavjanovedenie, op. cit., Prilożenija, s. LXXXПI. Zob. również S. I. Klimovs'kij, Medal' Janusa Radziwilla jak sviddennja pro seredn'ovicnij gerb Kieva, w: „Ukrains'kij Istoricnij Zurnal” 1992, nr 2, s. 40.

${ }^{14}$ M. I. Suchomlinov, Issledovanija $i$ stat'i po russkoj literature $i$ prosveš́entju, SPb 1889, t. I, s. 235.

is Biblioteka PAN, rkps. 1266, k. 47.

16 Tamże, k. 47 v, k. 52 v. Daniłowicz na tyle poznal język rosyjski, że mógł w tym języku prowadzic wykłady. Jednak jeszcze w 1829 r. korzystał z pomocy w korygowaniu swych pism urzędowych. Tamże, k. 81 - 82 v. Do thumaczenia Statutow wiślickich zachęcal Daniłowicza Nikokaj Rumiancew. Patrz: V. A. Francev, Pol'skoe slavjanovedenie, op. cit. Prilożenija, s. LXXXI.

${ }^{17}$ D. Bagalej, Opyt istorii Char'kovskogo universiteta, t. II (s 1815 po 1835 god), Char'kov 1904, s. 360, A. Cerkas, Danilovic Ignatij, op. cit., s. 73. 
profesorach, którzy „(...) swe rzeczy zwyczajnie jak pacierz trzepią", w uniwersytecie spotkał jednakże i ludzi interesujących ${ }^{18}$. Jeszcze w czerwcu 1825 r. donosił Lelewelowi: „Znalazłem kilku kolegów mniej egoizmem powodowanych, słodzą mi gorzkie chwile" ". Do charkowskich przyjaciół Daniłowicza zaliczyć można: Piotra Hułaka-Artemowskiego, Wasyla Komliszyńskiego, Jakowa Gromowa, Iwana Suchomlinowa i Andrzeja Dudrovicia. Z innych profesorów pozytywnie oceniał Iwana Kroneberga - „rosyjskiego Niemca", który w uniwersytecie prowadził wykłady $\mathrm{z}$ historii starożytnego Rzymu, wiele miejsca poświęcając komentarzom pism Tacyta i Cycerona. "Zna on niemieckie uniwersytety - stwierdzał - ma o nich nieco czystsze od naszych kolegów wyobrażenie"20. Za pośrednictwem Piotra Köppena nawiazał znajomość z jego rodzina mieszkajaca w Charkowie. W sierpniu 1825 r. Bobrowski informował bowiem Lelewela: „Jak się domyślam, kupidyn musiał trafić w serduszko naszego Ignasia, bo pisze: że na wdzięczącą się et quidem nie szpetna siostrzyczkę czy matki, czy siostry Pana Köppen każą mu zwracać oczy" ${ }^{21}$.

W grudniu 1825 r. odwiedził Daniłowicza Adam Mickiewicz, który w drodze z Odessy do Moskwy przejeżdżał przez Charków. Mimo znacznej odległości od Wilna, miasto to już w czasie studiów nie było mu obce. Wiedział, że w Charkowie istnieje Katedra Języka Polskiego zajmująca się nie tylko praktyczną nauką języka, ale i literaturą polską ${ }^{2}$. Polscy badacze czasów pobytu Mickiewicza w Rosji o wydarzeniu tym wspominaja raczej incydentalnie ${ }^{23}$. Fakt ten znany jest natomiast dość dobrze z literatury ukraińskiej, przede wszystkim zaś z prac Jeremija Ajzensztoka i Hryhorija Werwesa ${ }^{24}$. Sam poeta w liście z Moskwy do Antoniego Edwarda Odyńca, datowanego na 22 lutego (6 marca) 1826 r., pisał: „Co się tyczy moich poezji drukowanych zaocznie, pierwszy raz ujrzałem je w Charkowie z niemałym gniewem" ${ }^{25}$. Chodziło o wiersze Mickiewicza drukowane, jak się wydaje, bez jego wiedzy w „Dzienniku Warszawskim”, które mógł znaleźć w Charkowie tylko u Daniłowicza. Nie wykluczone, że będąc w tym mieście poeta odwiedził także i Hułaka-Artemowskiego. Nikołaj Sawicz, aktywny czlonek Bractwa Cyryla i Metodego, który przebywając

18 Biblioteka PAN, rkps. 1266, k. 60.

19. Tamże, k. 47.

20 Tamże, k. 60. Iwan Kroneberg (1788-1838) urodzony w Moskwie, profesor i rektor Uniwersytetu Charkowskiego, filolog klasyczny, autor prac: $O b$ obrazach $i$ obycajach dreunich rimljan ( $O$ iyciu $i$ obyczajach dawnych Rzymian), Rimskije drevnosti (Rzymskie starożytności), a także słownika łacińsko-rosyjskiego. Patrz: M.

I. Suchomlinov, Issledovanija $i$ stat'i po russkoj literature $i$ prosvesceniju, op. cit., t. I, s. 110-111. Jako o współpracowniku czasopisma "Moskowski Nabludatel" (Moskiewski Obserwator") wspominał o nim Wissarion Bieliński w liście do Iwana Panajewa z 10 VIII 1838 r. Patrz: I. Panajew, Wspomnienia literackie, Warszawa 1955, przeklad z ros. J. Dmochowska, s. 301; V. G. Belinskij v vospominanijach sovremennikov, Mosk va 1977, s. 189.

21 V. A. Francev, Pol'skoe slavjanovedenie, op. cit, Prilożenija, s. LXXXI.

$2 \mathrm{H}$. Werwes, Tam, gdzie Ikwy srebrne fale piynq. Z dziejów stosunków literackich polsko-ukrainskich w XIX i XX wieku, Warszawa 1972, s. 31. Po wyroku, jaki zapadł w procesie filaretów, rektor Uniwersytetu Wileńskiego Józef Twardowski w liście do Nikołaja Nowosilcowa z 24 IX 1824 r. pisał, że Józef Jeżowski i Mickiewicz ze względu na stan zdrowia wymagaja łagodnego klimatu i prosił, aby zostali zatrudnieni w Liceum Odesskim lub też w Uniwersytecie Charkowskim. Podkreślał, że Mickiewicz jest dobrym pisarzem (un bon ecrivain polonais», zaś w Uniwersytecie Charkowskim jest katedra literatury polskiej, w której bylby szczęśliwy, gdyby mógł pracowac. Patrz: Mickevic nakanune vosstanija dekabristov. Mickevic v Odesse, w: Literaturnoe nasledstvo. Dekabristy - literatory $I I$, t. 60, kn. 1, Moskva 1956, s. 419. Katedra jezyka i literatury polskiej w Uniwersytecie Charkowskim istniała do 1831 r, kiedy to w wyniku represji popowstaniowych decyzja kuratora Charkowskiego Okręgu Naukowego Władimira Fitatiewa zostata zlikwidowana. Patr: D. I. Bagalej, N. F. Sumcov, V. P. Buzeskul, Kratkij očerk istorii Char'kouskogo universiteta za pervye sto let ego suß̌estvovanija (1805-1905), Char'kov 1906, s. 70.

${ }^{23}$ W. Mickiewicz, Zywot Adama Mickiewicza podlug zebranych przez siebie materialow oraz $z$ wlasnych wspomnien opowiedzial Wadyslaw Mickiewicz, Poznań 1890, t. I, s. 221-222; L. Gomolicki, Dziennik pobytu Adama Mickiewicza w Rosji 1824 - 1829, Warszawa 1949, s. 107. O fakcie pobytu Mickiewicza w Charkowie brak wiadomości u S. Fiszmana, Mickiewicz w Rosji. Z archiwów, muzeów, bibliotek Moskwy i Leningradu, Warszawa 1949.

24 I. Ja Ajzenštok, Do perebuvannja Mickevica na Ukraini (Adam Mickievic i P. Gulak-Artemovs'kuj), w: Miżslovjans'ki literaturni vzaemini (zb. stat.), Kiiv 1958, s. 99 i n.; H. Verves, Adam Mickevic v ukrains'kij literaturi, Kiiv 1955, s. 57.

${ }^{25}$ A. Mickiewicz, Dziela t. XIV: Listy. Część I, Warszawa 1953, s. 258. 
w Paryżu przekazał Mickiewiczowi egzemplarz Kobzarza Tarasa Szewczenki, utrzymywał, że po raz pierwszy spotkal go w charkowskim mieszkaniu Hulaka-Artemowskiego ${ }^{26}$.

Dużą zasługą Daniłowicza było też spopularyzowanie w Uniwersytecie Charkowskim dorobku naukowego Lelewela. Daniłowicz należal nie tylko do przyjaciół wybitnego historyka, ale był również wielbicielem jego talentu. W liście do Lelewela z 21 lutego $1826 \mathrm{r}$. nadmienial. „Z niecierpliwością ksiąg drugich bibliografícznych wyglądam" ${ }^{27}$. Nieomal dwa lata później informował go, że prosil Zawadzkiego (chodzi o znanego księgarza wileńskiego Józefa Zawadzkiego - przyp. A. K.), aby ten prace Lelewela przesłał do Charkowa ${ }^{28}$. Rezultatem tych zabiegów był wybór Lelewela 31 października 1828 r. na honorowego członka Towarzystwa Nauk przy Uniwersytecie Charkowskim ${ }^{29}$. Lelewel nigdy Charkowa nie odwiedził, jednakże $z$ uczonymi charkowskimi i z bibliotekq̨ uniwersytecka musiał mieć kontakty, gdyż po wielu latach w liście do Seweryna Gałęzowskiego, zamieszkałego w Paryżu, wspominał: ,Z moich zaś z zakładami naukowymi relacji albo wcale mię nie naglących, albo nic nie wymagających mog̨̨ się liczyć następujące: biblioteki uniwersytetu Moskwy i Charkowa, bo z tymi uniwersytetami braterskie były stosunki" 30 .

Zasługi Daniłowicza w propagowaniu polskiego dorobku naukowego tak w Charkowie, jak i w Petersburgu i Moskwie, były niemałe. W ich uznaniu Warszawskie Towarzystwo Przyjaciół Nauk w styczniu 1829 r. powołało go na swego członka ${ }^{31}$. Druga dziedzina która przyniosła mu uznanie nie tylko współczesnych, stała się problematyka litewsko-ruska. W sprawach tych w sposób kompetentny wielokrotnie zabierał głos na łamach czasopism rosyjskich i polskich. $\mathrm{Z}$ momentem przejścia Daniłowicza do Petersburga do II Wydziału Kancelarii Cesarskiej, Uniwersytet Charkowski utracił wartościowego uczonego i nauczyciela ${ }^{32}$.

Dość nieoczekiwanie w Charkowie znalazł się również mineralog zoolog i podróżnik Jan Krynicki, uczeń Ludwika Bojanusa i Stanisława Bonifacego Jundziłła, pomocnik Józefa Jundziłła w naukowej wyprawie zorganizowanej latem $1821 \mathrm{r}$. na trasie od Wilna, poprzez Kowno, wzdłuż doliny Wilii i dalej ku morzu aż do Połągi ${ }^{33}$. Związany z filaretami, w październiku 1823 r. wraz z innymi aresztowany, dekretem z 14 sierpnia $1824 \mathrm{r}$. administracyjnie zesłany został $w$ głąb Rosji ${ }^{34}$. Staraniem prorektora Uniwersytetu Charkowskiego, Andrzeja Dudrovicia, w 1825 r.

26 "Kievska Starina” 1904, nr 2, s. 235-236 (nekrolog Nikobaja Sawicza).

27 Biblioteka PAN, rkps. 1266, k. 54. Bibliograficznych ksigg dwoje, t. 1 -2 ukazało się w Wilnie w roku $1823-1826$.

23 Tamże, k. 76: list z 28 I 1828 r.

* Ucenye obscestva i ucebno-vspomagatel'nye učreżdenija Char'kovskogo universiteta (1805 - 1905), Char'kov 1911, s. 216; J. Lelewel, Materialy autobiograficzne, w: J. Leleweh, Dziela, t. L, Warszawa 1957, s. 66. Borys Popkov pisze, ze czlonkiem Towarzystwa zostal dopiero w styczniu 1829 r., co jest blędem. Patrz: B. S. Popkov, Pol'skij uðenyj i revoljucioner Ioachim Lelevel'. Russkaja problematyka i kontakty, Moskva 1974, s. 54; tenże: I. Lelevel' i Ukraina, w: „Voprosy Istorii Slavjan", Voroneż 1977, vyp. 5.

${ }^{10}$ Listy emigracyjne Joachima Lelewela, wyd. H. Wieckowska, t. IV, Wroctaw-Kraków 1954, list ar 988 (z 7 VI 1850 r.) s. 66.

31 Biblioteka PAN, rkps. 1266, k. 77 - 78, 81 - 84; A. Kraushar, Towarzystwo Warszawskie Przyjaciól Nauk, k8. III: Ostatnie lata 1828-1830, Kraków - Warszawa 1905, s. 271, 483 - 484 (list Daniłowicza do Lelewela z 25 XII 1829 r. z podziękowaniem za wybór).

${ }^{32}$ W 1828 r. W prasie polskiej i rosyjskiej ogloszono konkurs na obsadę katedry prawa krajowego w Uniwersytecie Wileńskim, którą po opuszczeniu w 1824 r. przez Danilowicza zajął mgr Aleksander Kurowicki. Do konkursu stanął także przebywający w Charkowie Danilowicz, który go wygrał. Bobrowski w liście do Lelewela pisał nawet: ....) że się nadarza (...) okoliczność sprowadzenia Ignacego ze stolicy Chachlów do stolicy Jagiełłów". Patrz: A. V. Francev, Pol'skoe slavjanovedenie, op. cit, Prilożenija s. LXXX VII: list z października 1829 r., Wobec zatrudnienia Danilowicza w pracy nad Statutem litewskim w Petersburgu Kurowicki pozostał na katedrze w Wilnie. Patrz: R. W. Wołoszyński, Polsko-rosyjskie zwiqzki w naukach spolecznych, op. cit., s. 427.

${ }^{33}$ J. Jundzilt, Raport (...) z podróży botanicznej po guberni wileńskiej, w: „Pamiętnik Farmaceutyczny Wileński” 1822, t. 2, nr 2, s. 307 - 311 (trasa podróży), nr 3, s. 438 -446, nr 4, s. 574 - 587 (rezultaty podróży); Wklad wilesskiego ośrodka naukowego w przyrodnicze poznanie kraju (1781-1842). Praca zbiorowa pod red. J. Babicza i W. Grębeckiej, Wroclaw-Warszawa-Kraków-Gdańsk-Lódź 1988, s. 66, 241, 252.

34 Archiwum Filomatów, Cz II: Materialy do historii Towarzystwa Filomatów, t. III, wyd. S. Pietraszkiewiczówna, Kraków 1934, s. 405, 458 - 459, 475-476, 494 - 495. Minister Aleksander Szyszkow w swym raporcie 
powołano go na wykładowcę mineralogii w Charkowie ${ }^{35}$. Szybko awansowal: w $1826 \mathrm{r}$. został adiunktem, w 1828 - profesorem nadzwyczajnym, a w 1834 - profesorem zwyczajnym $^{36}$. Uporządkował i skatalogował gabinet mineralogiczny. „Zasługa Krynickiego dla Charkowskiego Uniwersytetu - pisał Antoni Stanisławski - w szczególności zależy na uporządkowaniu, a raczej na utworzeniu gabinetu mineralogicznego i zoologicznego. Zaraz po przybyciu jego do Charkowa, przyjąwszy w zawiadywanie swoje tak zwane muzeum mineralogiczne, znalazł je Krynicki w opłakanym nieładzie. Pracując cały rok z nadzwyczajną pilnością, opisał z górą 7000 przedmiotów wchodzących w skład tego muzeum i rozłożył je według systematu Wernera. Systematyczny ten katalog, mnóstwem objaśnień Krynickiego bogaty, zawiera się $w$ dwóch ogromnych księgach in folio i przechowuje się po dziś dzień w gabinecie mineralogicznym" ${ }^{37}$. Od śmierci prof. François de Lavigne'a (zm. w 1826 r.) wykładał równiez zoologię i zarządzal gabinetem zoologicznym, który dzięki niemu właściwie dopiero $w$ uniwersytecie powstał. Dla jego wzbogacenia prowadził intensywne poszukiwania $w$ południowej Rosji, nawiązał też kontakty $z$ wieloma zoologami w Europie i wymieniał z nimi ciekawsze okazy. Tatiana Passek, żona Wadima Passka, znanego historyka i etnografa, przyjaciela Aleksandra Hercena z czasów uniwersyteckich, wspomina, że: „Ze szczególnym zainteresowaniem badał pajęczaki i posiadał znacząca ich kolekcję w szklanych słojach" 38 . Krynicki związał się z Charkowem na trwałe. Posiadał dom $\mathrm{z}$ niedużym ogrodem. Jedno $\mathrm{z}$ pomieszczen oficyny wynajmował studentowi Wydziału Lekarskiego, Iwanowi Kaliniczence, znanemu później w mieście lekarzowi i profesorowi Uniwersytetu Charkowskiego ${ }^{39}$.

Krynicki pozostawił publikacje w językach: polskich, łacińskim, francuskim oraz w rosyjskim $^{40}$. W 1828 r. opublikował Spis celniejszych owadów zebranych w okolicach Charkowa i Odessy, opisał też mięczaki Ukrainy ${ }^{41}$. Korespondował z wybitnymi przyrodnikami pochodzenia niemieckiego pracującymi w Rosji: Gorhelfem Fischerem von Waldheimem i Edwardem Karolem Eichwaldem ${ }^{42}$.

z 16 (28) XI 1824 r. złożonym w sprawie filaretów Aleksandrowi I pisał, że Krynicki z powodu gruntownej znajomości historii naturalnej chciałby pracować w ogrodzie botanicznym. Patrz: L. Gomolicki, Dziennik pobytu Adama Mickiewicza w Rosji, op. cit., s. 14-15.

${ }^{35}$ M. I. Suchomlinov, Issledovanija $i$ stat'i po russkoj literature $i$ prosvesceniju, op. cit., r. I, s. 236.

${ }^{36}$ D. I. Bagalej, Opyt istorii Char'kouskogo universitet a, op. cit., t. II, s. 300, 328, 353, 424, 441, 459-466 i in.; M. A. Maksimovic, Ob ucenych trudach prof. zoologii i mineralogii $v$ Char'kovskom universitete I. A. Krynickiego, w: „UČenye zapiski Moskovskogo universiteta” 1833, t. I, s. 710-712; T. Lipiński, Polacy w Charkowie, w: „Znicz" Kalendarz informacyjny z dzialem literackim na rok zwyczajny 1905 [R. 1], Moskwa: Nakładem Rzymsko-Katolickiego Towarzystwa Dobroczynności, s. 78-79; Z. Kosiek, Krynicki Jan w: PSB, t. XV, Wroclaw - Warszawa-Kraków 1970, s. 462-463; B. Z. [Barbara Zielińska], Krynicki Jan w: Slownik biologów polskich, red. S. Feliksiak, Warszawa 1987, s. 303.

${ }^{37}$ A. Stanistawski, Zyciorysy. Wspomnienia o profesorach Polakach w Uniwersytecie Charkowskim. I. Śp. Jan Krynicki, w: "Gazeta Codzienna" 1860, nr 175, s. 4.

${ }^{36}$ T. P. Passek, Iz dal'nich let. Vospominanija, t. II. Moskva 1963, s. 200.

39 Tamże, s. 201. Po śmierci Krynickiego Iwan Kaliniczenko opublikowal trzy krótkie artykuły poświęcone jego życiu i działalności, w których wymienił także ważnejsze prace zmarłego. Patrz: „Zurnal Ministerstva Narodnogo Prosvešcenija” 1839, Pribavlenie, s. 18-24; „Bulletin de la Société Impériale des Naturalistes de Mascou” 1939, nr 12, s. 25-33 oraz „Tygodnik Petersburski” R. X, 1839, nr 37, s. 209-211. Iwan Kaliniczenko (1805-1876), lekarz, od $1840 \mathrm{r}$. profesor zwyczajny Uniwersytetu Charkowskiego, autor hasel z botaniki, medycyny i mineralogii do Encyklopedycznego leksykonu. Patrz: „Zurnal Ministerstva Narodnogo Prosvesčenija” 1840, nr 1 (genvar'), otd. III, s. 12-13, nr 6 (ijun'), otd. I, s. 178. O Kaliniczence patrz także: L. Ničpaevskij, Vospominanija. O Char'kovskom universitete. 1823 - 1829 gody, w: „Russkaja Starina” 1907, t. 131, kn VIII (avgust), s. $399-400$.

${ }^{40}$ Dorobek Krynickiego obejmuje 30 prac, z których 11 pozostało w rękopisie. Za A. Stanisławskim ("Gazeta Codzienna" 1860, nr 176) tytuły ważniejszych prac wymienia Róziewicz, Polsko-rosyjskie powiqzania naukowe (1725-1918), Wrockaw-Warszawa-Kraków-Gdańsk 1984, s. 238.

${ }^{41}$ Historia nauki polskiej, t. II, 1795 -1862, Wroclaw - Warszawa - Kraków-Gdańsk 1977, s. 510, 511, 517.

42 Gothelf Fischer von Waldheim (1771 - 1853), przyrodnik, mineralog i paleontolog. Przyjaciel Aleksandra Humboldta, Józefa Franka, George'a Cuviera i wielu innych znanych przrodników przelomu XVIII/XIX w. Profesor Uniwersytetu Moskiewskiego, wspólorganizator Towarzystwa Badaczy Natury w Moskwie. Czlonek 
W 1835 r. odbył podróż naukową na Kaukaz i nad brzegi mórz: Czarnego i Kaspijskiego. Oprócz badań przyrodniczych powierzono mu misję wizytowania szkół na Kaukazie, podlegających Charkowskiemu Okręgowi Naukowemu. W drodze powrotnej zachorował i po blisko czteroletniej chorobie zmarł 12 (24) września 1838 r. w Georgijewsku.

Poza działalnością naukową wielką pasją Krynickiego, o której wspomina Tatiana Passek, były polowania ${ }^{43}$. Odnośnie ich Stanisławski pisał: „(...) można powiedzieć, że je lubił namiętnie, chociaż w zabawce tej nie tyle chodziło mu o zwierzynę, ile o badanie życia i skłonności zwierząt i ptaków oraz o skompletowanie zoologicznego zbioru"44.

Jan Krynicki, pracując w Uniwersytecie Charkowskim, nie zapomniał o przyjaciołach z czasów wileńskich. Utrzymywał również kontakty z niewielką grupą Polaków mieszkających wówczas w Charkowie. Nigdy nie zerwał związków z polskością. Pochowany został w Charkowie na niezachowanym do dzisiaj cmentarzu katolickim. Tymczasem w drugiej połowie XIX w. zaczęło się zawłaszczanie go przez naukę rosyjską. Zapomniano o jego polskim pochodzeniu. Informacje encyklopedyczne umieszczały go pod hasłem Iwan Andriejewicz Krinickij, sugerując jego rosyjskie pochodzenie ${ }^{45}$.

Nie udało się natomiast związać z Charkowem innemu filarecie- Józefowi Jeżowskiemu (uczniowi Ernesta Grodka), który skazany na osiedlenie w oddalonych od Polski guberniach, do Rosji wyjechał w końcu października 1824 r. wraz z Franciszkiem Malewskim, Janem Sobolewskim i Adamem Mickiewiczem ${ }^{46}$. Przebywając w Odessie, czynił starania o zatrudnienie go w Uniwersytecie Charkowskim. Etatu jednak nie otrzymał. Charkowska klasyka obsadzona była w tym czasie przez profesorów Wasyla Dżunkowskiego i Iwana Kroneberga oraz Polaka Pawła Kunickiego (adiunkta od 1820 r.) ${ }^{47}$. W liście do Onufrego Pietraszkiewicza z 1 (13) maja 1825 r. thumaczył: „Otrzymałem od Krynickiego na list mój odpowiedź, w której donosi, że w Charkowie wcale wakansów nie ma, że wiele jest niedogodności, radzą oba (Jan Krynicki i Ignacy Daniłowicz), aby się trzymać literatury greckiej w Moskwie" 48. Po dwóch latach pracy w Moskwie w charakterze nauczyciela języków klasycznych w gimnazjum ponowił prośbę dotyczącą zaangażowania w Charkowie. W grudniu $1827 \mathrm{r}$. informował Lelewela o możliwości zatrudnienia go jako adiunkta w Katedrze Literatury Greckiej w tamtejszym uniwersytecie ${ }^{49}$. Propozycja okazała się jednak

honorowy Cesarskiego Towarzystwa Lekarskiego w Wilnie (1822), cłonek korespondent Warszawskiego Towarzystwa Przyjaciół Nauk (1830). Patrz: „Pamiętnik Farmaceutyczny Wileński”, t. IL, Wilno 1822, nr 4 s. 678; Encyklopedia powszechna Orgelbranda, t. 8, Warszawa 1861, s. 939-940.

Edward Karol Eichwald (1795-1876), przyrodnik i podróżnik, urodził się $w$ Mitawie w rodzinie kurlandzkiej szlacheckiego pochodzenia. Doktoryzował sie w $1819 \mathrm{r}$. w Wilnie na podstawie pracy z ichtiologii. W latach 1823 - 1826 kierował katedra anatomii porównawczej na Uniwersytecie Kazańskim. Od 1827 r. aż do zamknięcia uniwersytetu profesor katedry zoologii w Wilnie. Patrz: PSB, t. VI, Kraków 1948, s. 210-211.

${ }_{43}$ T. P. Passek, Iz dal'nych let, op. cit., t. II, s. 200.

4 A. Stanisławski, Zyciorysy. Wspomnienia o profesorach Polakach w Uniwersytecie Charkowskim, op. cit, nr 176, s. 4.

${ }^{45}$ Krinickij Ivan Andreevic, w: Russkij biografičeskij slovar', t. 9, SPb 1903, s. 443 - 444. Patrz także: Heleniusz [Eustachy Antoni Iwanowski], Wspomnienia polskich czasów dawnych i późniejszych, Lwów 1894, t. II, s. 233. Oceny postawy Krynickiego w literaturze rosyjskiej są pozytywne. Do odosobnionych należy opinia Niczpajewskiego, w latach 1823-1829 studenta Wydziału Lekarskiego Uniwersytetu Charkowskiego, który w swych wspomnieniach zanotował. „Katedre mineralogii po Taubergu zająl przysłany z Uniwersytetu Wileńskiego adiunkt Krynicki, człowiek, jak się okazało, o ponurym nastroju, zawsze posępny, choć jeszcze nie byl stary". Patrz: L. Ničpaevskij, Vospominanija o Char'kovskom universite. $1823-1829$ gody, op. cit, s. 381.

46 Kronika życia i twórczości Mickiewicza, t. 1: Lata 1798-1824, op. cit, s. 482-483.

${ }^{47}$ M. I. Suchomlinov, Issledovanija $i$ stat'i po russkoj literature i prosvešceniju, op. cit., t. I, s. 237. Patrz także: J. Bieliński, Uniwersytet Wilensski (1579-1831), t. II, Kraków $1899-1900$, s. 814.

4 Archiwum Filimatów, t. I: Na zeslaniu, pod red. Cz. Zgorzelskiego, Wrockaw-Warszawa-Kraków-Gdańsk 1973, s. 87. W liście do Pietraszkiewicza wysłanym w miesiąc później, 12 (24) VI 1825 r. pisat: „Ja, otrzymawszy wiadomośc, że w Charkowie nie ma dla mnie stosownego placu, w Moskwie zaś jest wakans, podałem w drugiej połowie przeszłego miesiąca prośbę do Ministra, prosząc go, aby mnie z woli wlasnej positive naznaczył nauczycielem greckiej literatury w Moskwie i wyrazilem takiej prośby powody"; tamże, s. 95.

4 Biblioteka Jagiellońska, rkps 4435, vol. 2, k. 90. 
ponownie nierealna. $\mathrm{Z}$ materiałów zebranych przez Wiktora Hahna wynika, że w połowie lat trzydziestych XIX w. ubiegał się on w Charkowie o profesurę, lecz również bez powodzenia ${ }^{50}$.

Niektórzy z autorów, glównie Polacy, do profesorów charkowskich polskiego pochodzenia zaliczają także Andrzeja Dudrovicia, ucznia Johanna Schada, który w uniwersytecie przez kilkanaście lat wykładał logikę, etykę i historię filozofii ${ }^{\text {s1 }}$. Teodor Lipiński, autor pracy Polacy w Charkowie wspomnial, że jednym z pierwszych polskich osiedleńców w tym mieście był: „(...) profesor i rektor Uniwersytetu Charkowskiego Andrzej Dudrowicz (1783 - 1830)" 52 . Za Lipińskim wiadomość te powtórzył Zygmunt Lukawski ${ }^{53}$. Jerzy Róziewicz wymienił go wśród Polaków, dodając jednak, że być może z pochodzenia był Serbem ${ }^{54}$. Andrzej Dudrovic, sprowadzony do Charkowa w 1812 r. przez Stojkovicia, rzeczywiście był Serbem ${ }^{55}$. Życzliwy stosunek do Polaków, zwłaszcza do Daniłowicza, z k tórym był zaprzyjaźniony, później zaś do Krynickiego, spowodował, że kojarzono go z Polakami. Dodatkowym argumentem na rzecz identyfikacji Dudrovicia z nacja polską był fakt, że to dzięki jego staraniom w Charkowie powstał pierwszy kościól katolicki, później zaś katolicka parafia ${ }^{\mathrm{s}}$.

Druga, liczebnie większa grupa uczonych Polaków pojawiła się w Charkowie w latach trzydziestych XIX w. już po zamknięciu Uniwersytetu Wileńskiego. Do najbardziej znanych, którzy w Uniwersytecie Charkowskim chlubnie kontynuowali tradycje wileńskiej wszechnicy, należeli Alfons Walicki i Aleksander Mickiewicz.

Alfons Walicki, który przez blisko 23 lata jako profesor zwyczajny kierował w Charkowie Katedrą Języka i Literatury Greckiej, był uczniem Ernesta Grodka". Niezwykle zdolny, będąc kandydatem filozofii, w 1828 r. wyprawiony został do Petersburga, gdzie w Akademii Nauk złożył egzamin konkursowy. Skierowany do tzw. Instytutu Profesorskiego przy uniwersytecie w Dorpacie, poglębil znajomość świata starożytnego ${ }^{58}$. W $1833 \mathrm{r}$. uzyskał stopień doktora filozofii i jako stypendysta ministerialny wyslany został na dwa lata do Berlina ${ }^{59}$. Po ukończeniu stażu skierowany do Charkowa stał się wkrótce ozdobą charkowskiej humanistyki ${ }^{60}$. „Sród ówczesnych

${ }^{s 0}$ W. Hahn, Józef Jeżowski w Rosji (1824-1855), w: Archiwum PAN w Warszawie, sygn. III - 82 (materialy W. Hahna), j. 14.

${ }^{51}$ M. I. Suchomlinov, Issledovantja $i$ stat'i po russkoj literature $i$ prosvesceniju, t. I, op. cit., s. 235.

52 L. Lipiński, Polacy w Charkowie, op. cit., s. 78.

${ }_{33}$ Z. Lukawski, Ludność polska w Rosji 1863 -1914, Wroctaw-Warszawa-Kraków-Gdańsk 1978, s. 41, 180.

4. J. Róziewicz, Polsko-rosyjskie powiqzania naukowe, op. cit., s. 237.

55 A. P. Bažova, Russko-jugoslavjanskie otnołenija vo vtoroj polovine XVII v., Moskva 1982, s. 198.

so Kościół katolicki w Charkowie erygowany został w końcu lat dwudziestych XXX w. Lipiński wspomina, że bylo to efektem zabiegów u metropolity Kaspra Kazimierza Cieszowskiego. Metropolitą mohylewskim został on w 1828 r. Patrz: T. Lipiński, Polacy w Charkowie, op. cit., s. 78; P. Nitecki, Biskupi Kościola w Polsce. Slownik biograficzny, Warszawa 1992, s. 39-40.

57 J. Bieliński, Uniwersytet Wileński (1579-1831), t. IL, Kraków 1899-1900, s. 491. R. W. Wołoszyński zaliczał go do pokolenia ostatnich ,pofilareckich" absolwentów Uniwersytetu Wileńskiego. Patrz: R. W. Wołoszyński, Polacy w Rosji 1801-1830, Warszawa 1984, s. 122.

58 Utworzonemu w 1827 r. przy uniwersytecie w Dorpacie Instytutowi Profesorskiemu powierzono kształcenie spośród absolwentów uniwersytetów rosyjskich specjalistów w zakresie antyku. Program studiów przewidywal staż zagraniczny w jednym z liczących się ośrodków badań nad starożytnościq, najczęściej na terenie Niemiec. Patrz: Istoriografia antičnoj istorii, red. V. I. Kuziščin, Moskva 1980, s. 75. Historia nauki polskiej, op. cit, t. III, s. 179 błędnie podaje, iż do Dorpatu trafil po likwidacji Uniwersytetu Wileńskiego. W rzeczywistości znalazl się tam znacznie wcześniej.

so Edward Czapski wspomina, że w latach 1833-1840 na Uniwersytecie Berlinskim liczba Polaków dochodziła do 200., wśród których ,Znakomici zdolnością (...) byli: Alfons Walicki, następnie dziekan fakultetu filologicznego na Uniwersytecie Charkowskim, autor doskonały, thumacz Fausta i nieodłązny jego towarzysz Iwanowski (chodzi o Ignacego Iwanowskiego, 1807 - 1886, profesora prawa międzynarodowego - przyp. A. K.) profesor Uniwersytetu Petersburskiego i Liceum"; Patrz: E. Czapski, Pamiftnik Sibiraka, Z przedmową S. Vincenza, rekopis opracowata M. Czapska i B. Świderski, Londyn 1964, s. 50.

${ }^{60}$ Walicki Alfons (1808-1858), w: Bibliografia literatury polskiej "Nowy Korbut", t. 9: Romantyzm, Warszawa 1972, s. 265-267; Bol'Saja enciklopedija, pod red. S. N. Jużakova i P. N. Miljukova, t. IV, SPb 1902, s. 329; Biograficeskij slovar' professorov Char'kovskogo universiteta, cast' 1: Istoriko-filologičeskij fakul'tet, pod red. M. Chalanskogo i D. Bagaleja, Char'kov 1908, s. 18 -19, 25, 31, 35, 66, 168; Z Lukawski, Ludnośc polska w Rosji 
profesorów Uniwersytetu Charkowskiego - pisał Lipiński - jaśniał tysiącem zalet i nader chlubną po sobie pozostawił sławę" ${ }^{\text {"1 }}$.

Do czasu opanowania języka rosyjskiego wykładał po łacinie. Był nie tylko wybitnym uczonym, ale i tłumaczem. Oprócz przekładów autorów starożytnych, między innymi Ajschylosa, Sofoklesa, Eurypidesa, przetłumaczył na jezyk polski Fausta część 1. oraz fragmenty Sagi o Frithjofie Esaiasa Tegnera. W 1848 r. w Charkowie ukazała się Cyropedia Ksenofonta (dzieło o wychowaniu Cyrusa), z uwagami rosyjskimi i słownikiem greckim. W piśmiennictwie polskim zapisał się również jako autor romantycznej tragedii $Z$ bigniew, nie wydanej drukiem, której jedynie część 1. zachowała się w zbiorach Biblioteki Narodowej ${ }^{62}$.

Michaił de Poule, wymieniając trzech profesorów Uniwersytetu Charkowskiego cieszących się dużą popularnością $\mathrm{i}$ autorytetem $\mathrm{w}$ latach trzydziestych-czterdziestych XIX w.: historyka Michaiła Lunina, filologa Alfonsa Walickiego i Tichona Stiepanowa z Wydziału Prawa ${ }^{63}$, dodaje, że „Walicki był bardziej lubiany niż Lunin. Ustawicznie oblegały go rzesze studentów, z którymi życzliwie rozmawiał $\mathrm{i}$ witał się, gdy tymczasem $\mathrm{z}$ Luninem studenci spotykali się niechętnie - a to $\mathrm{z}$ powodu braku oryginalności. Lunin nie lubil, by mu się kłaniano i sam nigdy nie zdejmowal swojego okragłego czarnego kapelusza, odpowiadajacc skinieniem głowy na ukłony studentów i, mimo próśb profesora, nie przestających, według rosyjskiego zwyczaju, zdejmować przed nim swoje czapki. Walicki zawsze okazywał się najbardziej aktywnym pomocnikiem w potrzebach studentów, najbardziej energicznym obrońca $w$ ich niedolach i zmartwieniach" ${ }^{\boldsymbol{6}}$. Uczeń $\mathrm{i}$ wielbiciel Lunina, Kostomarow, wypowiedział się w duchu podobnym, odnotowując: „Walicki wywarł na mnie nieco mniejszy wpływ niż Lunin, gdyż nie miałem ani właściwego przygotowania, ani też specjalnej motywacji, aby wybrać literaturę grecką i starożytność jako specjalizację; ale uczęszczałem na jego wykłady z dużą radością. Odnotujmy, że Walicki posiadał wspaniały dar wymowy i był w ogóle w przedstawianiu swego przedmiotu znacznie żywszy od Lunina" ${ }^{65}$.

O Walickim w Charkowie krążyło wiele anegdot. Opowiadano na przykład, że gdy przez Charków przejeżdżał znany uczony francuski baron de Barante, który zwiedzając uniwersytet zapragnął posłuchać wykładu, zaprowadzono go do audytorium, gdzie prowadził zajęcia Walicki. Po wejściu gościa na salę, profesor, przerywając swój wykład, po łacinie zaczął mówić o zasługach uczonych francuskich w badaniach starożytności klasycznych. Improwizacja oczarowała Francuza,

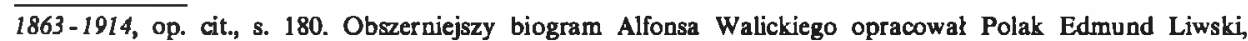
w latach 1845-1851 student historii Uniwersytetu Charkowskiego. W czasie studiów uczęszczal on na wykłady Walickiego, bywał u niego w domu. Na cmentarzu nad grobem Walickiego wygłosil mowę pożegnalną. Biogram nie został nigdzie opublikowany. Pozostaje on w rękopiśmiennej spuściźnie po Liwskim. Patrz: Biblioteka PAN w Krakowie, rkps 6610 .

${ }_{61}^{6}$ T. Lipiński, Polacy w Charkowie, op. cit., s. 79.

${ }_{2}$ M. Hłyń, Czasy piastowskie w literaturze pieknej romantyzmu, Poznań 1991 (maszynopis pracy doktorskiej napisanej pod kierunkiem prof. dr hab. Jerzego Strzelczyka), s. 299-301.

${ }^{63}$ Michail Lunin (1809-1844), profesor historii powszechnej, dziekan Wydziału Filologiczno-Historycznego Uniwersytetu Charkowskiego. Studiowal w Dorpacie, gdzie w 1832 r. obronil prace doktorska z filozofii. Artykuły z historii starożytnego Rzymu i historiografii Wschodu publikowal w "Żurnale Ministerstva Narodnogo Prosvešcenija" i w "Moskvitianinie”. Wykłady jego cieszyly się znaczn̨̧ popularnością. Edward Czapski, który uczęszczal na nie na poczq̨tku lat czterdziestych XIX w. pisal: „....) że bardzo szczegółowo opowiadał dzieje nowożytne, konkluzji nie wyciąając żadnych, ani nawet naprowadzal shuchaczów na ogólne poglady w jakimkolwiek kierunku"; patrz: E. Czapski, Pamietniki Sibiraka, op. cit., s. 69. Tichon Stiepanow (1795-1847), profesor ekonomii politycznej. W $1824 \mathrm{r}$. obronil prace magisterską na temat równowagi politycznej ( $O$ politiceskom ravnovesii). Autor wielu artykułów $\mathrm{z}$ ekonomii i filozofii drukowanych $w$ periodykach lat czterdziestych XIX w. W 1869 r. profesorem zoologii Uniwersytetu Charkowskiego zostal jego syn Pawel.

${ }_{6}^{4}$ M. de Pule, Char'kovskij universitet $i$ D. I. KaXenovskij. Kul'turnyj ocerk i vospominanija iz 40-ch godov, w: „Vestnik Evropy" 1874, nr 1, s. 95; tenże, w przekladzie na język polski (tekst nieco zmieniony) w „Bibliotece Warszawskiej" 1874 , t. IV, s. 484.

${ }^{65}$ N. I. Kostomarov, Istorileskie proizvedenija. Avtobiografia, 2-e izd., Kiev 1990, s. 442. „Walicki - pisał Czapski - swietnie bardzo wykładal literature grecką, oprócz tekstu poety albo historyka, nigdy nic innego nie mial pod ręką na katedrze. Lubiany był powszechnie przez młodzież, którą uczył i ożywiał, nie troszcząc się nigdy o czołobitność stuchaczów"; patrz E. Czapski, Pamiętniki Sibiraka, op. cit., s. 70. 
umacniając populamość Walickiego w środowisku uniwersyteckim ${ }^{66}$. Głośna była także wizyta w Charkowie Wissariona Bielińskiego, który o Walickim miał powiedzieć, że jest „gwiazdą pierwszej wielkościn ${ }^{n 7}$.

W 1855 r. przypadalo stulecie istnienia Uniwersytetu Moskiewskiego. Na uroczystościach tych Uniwersytet Charkowski reprezentowali profesorowie: Wasyl Lapszyn oraz Alfons Walicki. „Rada Uniwersytetu - wspominal Lapszyn - nie zatroszczyła się, aby przygotować odpowiednie pozdrowienie we wlaściwej, odpowiadającej uroczystościom formie, tak jak to było w zwyczaju. Wręczono nam pakiet zwykłych pism w przeddzień wyjazdu. Nie było czasu powiedzieć, że tak się nie godzi" ${ }^{\text {6 }}$. Po przjeździe do Moskwy Lapszyn i Walicki postanowili, aby mowę na cześć dostojnego jubilata wygłosić po lacinie. Niecodzienność święta i odpowiadająca dostojeństwu mowa wygłoszona przez ,(...) profesora Walickiego dźwięcznym głosem, słyszalnym przez licznie zgromadzone gremium wywarła ogromne wrażenie. Rozgwar na następnych spotkaniach i po całej Moskwie pochlebną opinią nagradzał mówcę"

Podobnie jak i inni profesorowie przybysze, Walicki osiadł w Charkowie na stałe. W 1837 r. ożenił się z Emilią Rozenówną z którą mial sześcioro dzieci ${ }^{x}$. Utrzymywał pensjonat dla studentów, który przynosił mu pewien dochód. Lubił towarzystwo, żywą rozmowę, zabawę ${ }^{7 !}$. Zmarł w pełni sił twórczych 12 (24) października $1858 \mathrm{r}$. Wiadomości o jego śmierci ukazały się nie tylko w prasie rosyjskojęzycznej, ale i w czasopismach Królestwa Polskiego ${ }^{2}$. W nekrologu zamieszczonym w „Przeglądzie Poznańskim” czytamy: „Kochano go i szanowano powszechnie, bo przymiotom jego jako człowieka naukowego odpowiadały przymioty serca. Zgon też jego rzucił

(6) M. de Pule, Char'kouskij universitet i D. I. KaCenovskij op. cit., s. 95-96. Guillaume - Prosper Brugière de Barante (1782-1866) historyk, krytyk literacki, dyplomata, autor licznych dzieł, wśród których szczególną poczytnością cieszyła się Historie de ducs de Bourgogne de la maison de Valois, t. 1 -8, Paris 1824-1826. W latach 1835-1841 ambasador francuski przy dworze Mikolaja I. Patrz: Dictionnaire de biographie francaise t. 5, Paris 1951, s. 177-181. Lazar Czerejski jako date urodzin Barante'a podaje 10 VI 1785 r. Patrz: L. A. Cerejski, Puskin i ego okruzienie, Leningrad 1975, s. 24. Barante jako ambasador występuje u A. de Custine'a, Rosja w roku 1839 , Warszawa 1995, t. I, s. 186, 210, 217, 218 i in. także w t. II (wedlug indeksu). Patrz także: Markiz de Kjustin, Nikolaevskaja Rossija, Moskva 1990, izd. „Terra”, s. 94, 247, 250-251, 261.

67 M. de Pule, Char'kovskij universitet i D. I. Kacenovskij, op. cit., s. 96.

v. I. Lapsin, Iz vospominanij, w: "Zurnal Ministerstva Narodnogo Presveščnija", čast CCLXIX, 1890, nr 5 (maj), s. 127.

69 Tamże, 8. 127-128. O uroczystościach tych i mowie Walickiego pisze także M. Pule, Char'kovskij universitet $i$ D. I. Kačenovskij, op. cit., s. 96.

${ }^{70}$ "Kronika Wiadomości Krajowych i Zagranicznych" R. 3, 1858, nr 323 z 23 XI]5 XII, s. 1.

"M. Poule pisze, że: „W przeciwieństwie do skrytości Lunina natura Walickiego była w dużym stopniu dynamiczna, namiętna, jeśli kto woli - szeroko slowiańska". Autor ten opisał również powierzchowność Walickiego. „Przy bardzo małym wzroście - czytamy tamże - Walicki byl doskonale zbudowany, urodziwy i posiadał nadzwyczaj silny i sympatyczny głos, przechodzący od miękkich dźwięlców altu do glębokiego barytonu; w całej jego niewielkiej postaci uwydatniało się czoło i wprawdzie nieduże, lecz miotające iskrami oczy"; patr: M. Pule, Char'kovskij universitet i D. I. KaCenovskij, op. cit., s. 93, 94. Natomiast Edward Roner pisal o nim: „Ze szkól wileńskich z Walickiego funduszu, z sąsiedniego domu naszemu na Sawicz ulicy wyszedł ten czlowieczek małego wzrostu, ale niepospolitego umyshu i dzielnego charakteru"; patrz: Nie ustawajmy więc w ochocie pisania... $Z$ dziejów Romerów na Litwie. $Z$ listów i dziennikow trzech pokolen, wybór, opracowanie i wstep D. Kamolowa, Warszawa 1992, s. 157. Charkowski dom Walickich był domem polskim. Kultywowano w nim języl i tradycje narodowe. Syn Alfonsa, Józef, w latach pięćdziesiątych student Wydziału Lekarskiego Uniwersytetu Charkowskiego (przyjety na uniwersytet 27 VIII 1856 r.) byl uczestnikjem powstania styczniowego. W wyniku represji popowstaniowych malazl się na Syberii. Wactaw Lasocki w swych wspomnieniach pisat. „Walicki Józef, syn znanego i ogólnie szanowanego profesora Uniwersytetu Charkowskiego Alfonsa Walickiego, wielkich zdolności i wykształcony młodzieniec, ale się zmarnował na wygnaniu, żeniąc się z Sybiraczką obrządku wschodniego". Patrz: W. Lasocki, Wspomnienia z mojego życia, przygotowali do druku M. Janik i F. Kopera, t. II: Na Syberii, Kraków 1934, s. 335.

72 "Kronika Wiadomości Krajowych i Zagranicznych" R. 3, 1858, op. cit, s. 1; „Biblioteka Warszawska” 1858, t. 4, s. 804; „Gazeta Warszawska” 1858, nr 305; „Dziennik Literacki” 1859, nr 1. Na marginesie wiadomości - śmierci Walickiego zamieszczonej w "Kronice Wiadomości Krajowych i Zagranicznych" czytamy: "W Charkowie dużo mieszka naszych rodaków; w uniwersytecie sł profesorami, nauczycielami w gimnazjach, wielu z nich było kiedyś uczniami Walickiego". 
żałobę na cały uniwersytet. Pogrzebowi towarzyszyła cała młodzież polska i rosyjska ucząca się w uniwersytecie i gimnazjach"?3.

Na rok przed Walickim przybył do Charkowa były wykładowca astronomii teoretycznej w Obserwatorium Uniwersytetu Wileńskiego, w latach 1824-1832 profesor geodezji w Wilnie, Antoni Szahin ${ }^{74}$. Po zamknięciu w 1832 r. uniwersytetu uczył matematyki w gimnazjum witebskim. W Uniwersytecie Charkowskim zatrudniony został najpierw w charakterze adiunkta, wkrótce potem zaś profesora astronomii ${ }^{7 s}$. W latach 1838-1842 w „Zurnale Ministerstwa Narodnogo Prosvešćenija" zamieścił kilka rozpraw dotyczących tak astronomii, jak i geodezji. Z natury spokojny i zamknięty w sobie, w życiu towarzyskim raczej nie uczestniczył. Jest postacią zapomniana. Poza opracowaniami dotyczącymi historii Uniwersytetu Charkowskiego, prawie nigdzie też nie został odnotowany ${ }^{76}$. Zmarł w Charkowie 18 (30) listopada $1842 \mathrm{r}$. i tam też został pochowany $n$.

To samo dotyczy Karola Klaudiusza Wiszniewskiego, absolwenta Wydziałyu Lekarskiego Uniwersytetu Wileńskiego, który w Charkowie przez 11 lat (1837-1848) kierowal Katedrą Weterynarii ${ }^{\text {T⿱ }}$.

Kilku profesorów - wychowanków Uniwersytetu Wileńskiego do Charkowa trafiło przez Kijów. Otwarcie w 1834 r. Uniwersytetu Kijowskiego z liczącą się populacją polską, zwłaszcza dla średniej generacji uczonych stanowiło nadzieję kontynuacji badań bądź też znalezienia pracy zgodnej z wcześniej wyuczoną profesją ${ }^{79}$. Mimo że władze rosyjskie niechętne były takiemu rozwiązaniu, zmusil je do tego niedobór kadry nauczającej widoczny w tym czasie w skali całego imperium. Zastrzeżenia natury politycznej ustąpiły przed potrzebami. Pocieszano się tym, że cały proces dydaktyczny, niezależnie od zaistniałej sytuacji, nadzorować i kształtować można będzie według potrzeb rządu. Sytuacja wymknęła się jednak spod kontroli. Wkrótce kilkudziesięciu studentów znalazło się w szeregach Związku Ludu Polskiego, niepodleglościowej organizacji

\footnotetext{
73 "Przegląd Poznański" R. 14, 1858, t. XXVI, s. 375.

74 J. Bieliński, Uniwersytet Wielński, op. cit., t. II, s. 42, 46, 47, 49, 52, 69, 91, $218-219,231-232$; t. III, s. 348-349. W 1829 r. w Wilnie ukazata się Jeodezya wyższa Szahina. Patrz: Wklod wileriskiego ośrodka naukowego w przyrodnicze poznanie kraju $1781-1842$, op. cit., s. 66 .

${ }^{3}$ D. Bagalej, Opyt istorii Char'kovskogo universiteta, op. cit., t. II, s. $448-551,497-498,502,579,589,592$, 1102; M. A. Tichomandrickj, Opyt istorii Fiziko-Matematiceskogo Fakul'teta Char'kovskogo universiteta, w: Zapiski Char'kovskogo universiteta, Char'kov 1904, t. IV, s. 52, 106; G. V. Levickij, Astronomy i astronomiceskaja observatorija Char'kovskogo univeristeta, w: Zapiski Char'kovskogo universiteta, Char'kov 1893, t. III, s. 1, 33 i n.

${ }^{76}$ E. K. Redin, Prepodavanie iskustv v Char'kovskom universitete, op. cit., s. 106; L. Janowski, Slownik biobibliograficzny dawnego Uniwersytetu Wilentskiego, wyd. pod kierunkiem R. Mienickiego, Wilno 1939, s. 426- 427.

${ }^{n}$ L. Janowski, Slownik biobibliograficzny dawnego Uniwersytetu Wileńskiego, op. cit, s. 426. J. Róziewicz jako datę śmierci Szahina podaje rok 1845; patrz J. Róziewicz, Polsko-rosyjskie powiqzania naukowe op. cit., s. 239; podobnie: F. M. S. [Franciszek Maksymilian Sobieszczański], Szahin Antoni, w: Encyklopedia powszechna Orgelbranda t. 24 , Warszawa 1867 , s. 531 .

${ }_{78}$ Wykaz prac w jezyku tacińskim i roysjskim wydanych w czasie, gdy był profesorem Uniwersytetu Charkowskiego podaje J. Bieliński, Uniwersytet Wilenski (1579-1831), op. cit, t. II, s. 382. Patrz także: J. Bieliński, Doktorowie medyc yny proklamowani w Winie, odbitka z „Pamiętnika Lekarskiego”, Warszawa 1886, s. 91: Biogragficeskij slovar' professorov Char'kovskogo universiteta, t. II: Fiziko-MMatematiceskij Fakul'tet, Char'kov 1908, s. 309-310; F. M. S. [Franciszek Maksymilian Sobieszczański], Wiszniewski Karol Klaudiusz, w: Encyklopedia powszechna Orgelbranda, t. 27, Warszawa 1867, s. $271-272$. W 1848 r. zrezygnowal z pracy w uniwersytecie, a nasteppnie przeniossł się na Podole i zamieszkał we whasnym majątku Werbka Woloska, liczącym ponad 500 dziesięcin. Zmarł 22 III 1863 r. Patrz: S. Kośmiński, Slownik lekarzów polskich, Warszawa 1888 , s. 550. L. Janowski jako date smierci Wiszniewskiego podaje rok 1860 . Patrz: L. Janowski, Slownik biobibliograficzny dawnego Uniwersytetu Wileniskiego, op. cit., s. 488. Majątek Werbka Woloska jeszcze w końcu XIX w. byl w posiadaniu rodziny Wiszniewskich. Patrz: Slownik geograficzny Królestwa Polskiego, t. XIII, Warszawa 1893 , s. 217.

79 Kievskij universitet. Dokumenty $i$ materialy 1834-1984, Kiev 1984, s. 14: ukaz carski o otwarciu uniwersytetu z 8 (20) XI 1833 r.; s. 15: wiadomość o uroczystym otwarciu uniwersytetu 15 (27) VII 1834 r. Michal Rolle pisze, ze łącznie 15. profesorów i innych pracowników Liceum Krzemienieckiego zatrudnionych zostało w Uniwersytecie Kijowskim. Patrz M. Rolle, Ateny Wolyriskie. Szkic z dziejdw oświaty w Polsce wyd. 2 popr. i uzup., Lwów - Warszawa - Kraków 1923, s. 255.
} 
założonej przez Szymona Konarskiego ${ }^{\star 0}$. Po aresztowaniu 27 maja 1838 r. Konarskiego (na stacji pocztowej Krzyżówka niedaleko Wilna) policja carska natrafiła na ślad konspiracji kijowskiej" ${ }^{\text {B1 }}$ W śledztwie pomógł jej były student Uniwersytetu Kijowskiego Julian Maciejowski. Zgłosił się on do bawiącego w Wilnie ministra Uwarowa, ujawniając wiele szczególów dotyczących istnienia organizacji studenckiej $w$ Kijowie oraz przekazując nazwiska najaktywniejszych jej czlonków ${ }^{82}$. Denuncjacja zapoczątkowała falę aresztowań. Wśród 115. zatrzymanych w Kijowie znalazło się 34. studentów $(29,6 \%)^{83}$. Śledztwem kierował osobiście generał gubernator Dmitrij Bibikow ${ }^{84}$. Car Mikołaj I na wiadomość o wykryciu spisku i zaangażowaniu w nim studentów, w większości Polaków, powziął zamiar likwidacji uniwersytetu. Później decyzję swoją nieco złagodził. Na początku stycznia 1839 r. $(9 / 21$ I) wydany został ukaz carski, na mocy którego uniwersytet na okres jednego roku zostal zamknięty ${ }^{85}$. Wszystkich studentów ze skutkiem natychmiastowym usunięto. Mieli oni być przesiedleni do innych uniwersytetów cesarstwa lub przyjęci do służby państwowej zarówno cywilnej, jak i wojskoweje ${ }^{86}$. Kilku wykładowców: Aleksandra Mickiewicza, Grzegorza Hreczynę, Antoniego Plansona i Bonawenturę Klembowskiego przeniesiono do Charkowa ${ }^{87}$.

Aleksander Julian Mickiewicz, młodszy brat Adama, w latach 1819-1822 studiowal na Wydziale Prawa Uniwersytetu Wileńskiego ${ }^{88}$. W 1822 r. za prace Jaki wplyw prawodawstwo rzymskie na prawodawstwo polskie i litewskie mieć moglo?, opatrzoną póżniej przypisami Lelewela

A. Barszczewska, Szymon Konarski, Warszawa 1976, s. 161. Za przelom w działalności Związlu przyjmuje Barszczewska połowę 1837 r., kiedy to Konarski znalazł silne oparcie w związkach studentów Akademii Medyko-Chirurgicznej w Wilnie, Uniwersytetu Kijowskiego i uniwersytetu w Dorpacie.

${ }^{81}$ H. Moscicki, Szymon Konarski, Warszawa 1949, s. 75-76. Już 28 V 1838 r. przeshuchiwał go książe Aleksiej Trubecki, wicegubernator wileński. Patrz: A. Barszczewska, Szymon Konarski op. cit., s. 225.

2. M. Vladimirskij-Budanov, Istorija Imperatorskogo Universiteta Sv. Madimira, t. I, Kiev 1884, s. 169.

${ }^{9}$ D. Beauvois, Polacy na Ukrainie 1831 - 1863. Szlachta polska no Wolyniu, Podolu i Kijowszczyznie, Paryż 1988, s. 216, 247; A. Barszczewska, Szymon Konarski, op. cit., s. 236.

${ }^{84}$ Dmitrij Gawriłowicz Bibikow (1792-1870), general, w bitwie pod Borodino stracil rękę. W końcu $1837 \mathrm{r}$. objął urząd generała gubernatora guberni kijowskiej, wolyniskiej i podolskiej. Piastowal go do 1852 r. U. Tabisia błednie jako Grzegorz Pawłowicz Bibikow. Patrz: J. Tabiś, Polacy na Uniwersytecie Kijowskim, 1834-1863, Kraków 1974, s. 57, 169. Ksiądz Tomasz Dobszewicz pisal o Bibikowie, że „Czlowiek to byl niemalycb zdolności, bystrego pojęcia, wymowny i do publicznego przemawiania ocboczy, wreszcie w obejściu swojem dość grzeczny. Obok zaś tego latwo się unosił, w zapale gniewu nie umiał miarkować ani słów, ani środków, i gdziekolwiek szło o wykonanie myśli i zamiarów rządu, nikogo nie oszczędzal, stąd o ile ceniony był przez cesarza, o tyle nie cierpiany od tych, którymi rządzil". Patrz: T. Dobszewicz, Wspomnienia z czasów, które przeżylem, Kraków 1883, s. 185.

${ }^{85}$ M. F. Vladimirskij-Budanov, Istorija Imperatorskogo Universiteta Sv. Vadimira t. I, op. cit, s. 178. Wiadomość o relegowaniu studentów i przeniesieniu ich do innych uniwersytetów tamże, s. $201,203$.

${ }^{86}$ Mylił się Zygmunt Szczęsny Feliński, stwierdzając, że „,...) w Kijowie wśród uczącej się młodzieży spisku nie wykryto, wydalonym przeto $z$ uniwersytetu studentom pozwolono gdzie indziej kończyć nauki. Kilkunastu $z$ tej kategorii [mowa o relegowanych - przyp. A. K.] przybyło także do Moskwy, inni udali się do Charkowa, Kazania lub Petersburga, ci zaś co whadali jezzykiem niemieckimn obrali raczej Dorpat"; patrz: Z. Sz. Feliński, Pamiętniki, opr., przyg. do druku i opatrzyl przedmową E. Kozłowski, Warszawa 1986, s. 140. Zarówno w pamiętnikach, jak i w literaturze spotyka się opinie, że częśc z obwinionych o spiskowanie studentów zesłano także „w soldaty” na Kaukaz. Patrz: W. Lasocki, Wspomnienia z mojego życia t. I: Wkraju, Kraków 1933, s. 160.

${ }^{77}$ M. Rolle, Ateny Wolyńskie. Szkice z dziejów oświaty w Polsce, op. cit., s. 258; J. Tabiś, Polacy na Uniwersytecie Kijowskim, op. cit, s. 26. W 1839 r. na 46. pracowników Uniwersytetu Charkowskiego 23. (50\%) było profesorami zwyczajnymi, 5. nadzwyczajnymi, 9. adiunktami oraz 8. wykładowcami. Spośród wymienionych 17. (37\%) bylo wychowankami Uniwersytetu Charkowskiego, 5. (11\%) Wileńskiego, natomiast 4. (niespelna 9\%) trafilo do Charkowa z uniwersytetu w Dorpacie. O tym jednak, że Polaków bylo wiẹcej niż 5 . świadczy to, że aż 11. $(24 \%)$ bylo wyznania rzymskokatolickiego, a tylko 5 . (11\%) protestanckiego. Nie wszyscy, ale zdecydowana większość spośród katolików w uniwersytecie stanowili Polacy. Patrz ,Zurnal Ministerstva Narodnogo Prosvešcenija" 1840, nr 10 (oktjabr'), odt. III, s. 4, 6, 10.

J. Bieliński, Uniwersytet Wileński (1579-1831), op. cit., t. II, s. 820; Z. Makowiecka, Mickiewicz Julian Aleksander (1801-1871), w: PSB, t. XX, z. 4, Wroclaw-Warszawa-Kraków-Gdańsk 1975, s. 706 (w biogramie błędy dotyczące studiów wileńsłich); Bibliografia literatury polskiej „Nowy Korbut”, t. 8: Romantyzm, Warszawa 1969, s. 378-379; E. Chw. [Edward Cbwalewski], Mickiewicz Aleksander, w: Wielka encyklopedia powszechna ilustrowana t. XLV-XLVI, Warszawa 1911, s. 1001. 
i wydrukowaną w „Dzienniku Warszawskim”, otrzymał drugą lokatę ${ }^{89}$. W 1825 r. uzyskał tytuł magistra praw. Od 1828 r. do konca istnienia Liceum Krzemienieckiego uczył w nim prawa polskiego, litewskiego, rzymskiego oraz encyklopedii praw ${ }^{90}$. Aleksander Kozieradzki, w latach 1828-1830 uczeń Mickiewicza, we wspomnieniach swych zanotował. „Wykładał sposobem uniwersyteckim, to jest dawszy uczniom tekst treściwy, na prelekcjach daleko obszerniej go tłumaczyl"'91. W latach 1834-1839 był profesorem, początkowo nadzwyczajnym, od $1836 \mathrm{r}$. zwyczajnym prawa rzymskiego na Uniwersytecie Kijowskim, skąd po zamknięciu uniwersytetu skierowany zostal do Charkowa ${ }^{\text {92 }}$. Niezbyt życzliwy Polakom Michaił Władimirski-Budanow pisząc, że w Kijowie stał na czele profesorów krzemienieckich snujących „bezpłodne wspomnienia minionych dni", dodaje jednak, że był utalentowanym uczonym, dorównującym wyzwaniom współczesnych mu czasów ${ }^{93}$. Niecałe dwadzieścia lat, to znaczy do momentu uzyskania prawa do emerytury (1858 r.), kierował w Charkowie Katedrą Prawa Rzymskiego ${ }^{94}$. Przez pierwsze lata wykładał po łacinie, później, pod presją władz, posługiwał się językiem rosyjskim, co jednak przychodziło mu z trudem ${ }^{95}$. W $1848 \mathrm{r}$. w Charkowie opublikował krótką rozprawę zatytułowaną Mowa o wlaściwościach prawa rzymskiego (De juris romani indole oratio).

Byl człowiekiem uczciwym, o dużym poczuciu sprawiedliwości. Nikołaj Ogier de Rancour, który w końcu lat trzydziestych XIX w. z Petersburga trafił do Charkowa, zanotowal: „Jedynie tylko profesor prawa rzymskiego Mickiewicz przeniesiony do Charkowa z byłego Uniwersytetu Wileńskiego (brat poety), jedynie on nie uległ demoralizacji, dlatego że był człowiekiem prawdy, lekcji nie dawał (chodzi o lekcje przed egazminami udzielane za odpłatnościq - przyp. A. K.) i nie znał obłudy. Gorliwie zajmowałem się jego przedmiotem, zawsze pomyślnie odpowiadałem na powtórkach, łacińskie cytaty znałem wyśmienicie i dlatego nie patrząc na niepelność i nieśmiałość odpowiedzi i na sprzeciw pomocnika kuratora, uważał on za sprawiedliwe postawić mi wysoką ocenęęm.

Mimo kontaktów z grupą Polaków mieszkających w Charkowie, Mickiewicz był zaprzeczeniem Walickiego. Aktywniejszego udziału w życiu towarzyskim nie brał. W $1841 \mathrm{r}$. poślubił Teresę Terajewiczównę, z którą miał syna Franciszka i córkę Marię" . Prowadził dom tradycyjny,

„Dziennik Warszawski” 1825, t. I, nr 4 (wrzesień), s. 457-502, t. II, nr 6 (listopad), s. 133 - 162. Przypisy
Lelewela do pracy Aleksandra Mickiewicza ukazywały się także i póniej w wydaniach pism wybitnego
historyka. Patrz min.: Materialy do dziejów polskich, Poznań 1847 (nakładem J. K. Zupańskiego), s. $233-247$
(Przypiski do dwu rozpraw Aleksandra Mickiewicza i Franciszka Morze o wplywie prawodawstwa rzymskiego na
polskie i litewskie).
${ }_{90}$ A. Slowikowski, Wspomnienia szkoly krzemienieckiej, w: „Biblioteka Warszawska” 1863, t. II, s. 344, 353; M. Rolle, Anteny Wolyniskie. Szkic z dziejów oswiaty w Polsce, op. cit., s. 70, 77; A. Wrzosek, Aleksander Mickiewicz, ostatni profesor prawa w dawnym Liceum Krzemienieckim, w: „Minerwa Polska” R. I, 1927, nr 1, s. $75-79$ (s. 77 -79: fragment wspomnień A. Kozieradzkiego). M. Danielewiczowa pisze, że w Krzemieńcu znalazł się już w 1827 r. Patrz: M. Danielewiczowa, Zycie naukowe dawnego Liceum Krzemienieckiego, w: „Nauka Polska” R. 22, 1937 , s. 72.

91 A. Kozieradzki, Wspomnienia z lat szkolnych 1820 -1831, wstęp napisal i komentarzem opatrzyl S. Kawyn, Wrockaw - Warszawa-Kraków 1962, s. 149.

${ }_{92}$ Z. Lukawski, Ludnośc polska w Rosji 1863-1914, Wroclaw-Warszawa-Kraków -Gdańsk 1978, s. 179; J. Róziewicz, Polsko-rosyjskie powiqzania naukowe, op. cit., s.226, 238.

${ }_{93}$ M. F. Vladimirskij-Budanov, Istorija Imperatorskogo Universiteta Sv. hadimira t. I, op. cit., s. 127.

94 D. I. Bagalej, N. V. Sumcov, V. P. Buzeskul, Kratkij ocerk istorii Char'kovskogo universiteta, op. cit., s. 133, $140-141,158-159$.

${ }^{5}$ M. Pule, Char'kouskij universitet i D. I. Kačenouskij, op. cit, s. 105. W Bibliotece PAN w Krakowie zachowały się rękopiśmienne łacińskie wykłady prowadzone przez Mickiewicza w Uniwersytecie Charkowskim (rkps. 1634).

* N. F. Oże de Rankur, V dvuch universitetach. Vospominanija 1837 - 1843 godov, w: „Russkaja Starina", t. 86, 1896, nr 6, s. 581. Nikołaj Ogier de Rancour (ur. 1821 r.) absolwent Uniwersytetu Charkowskiego, później pułkownik, dyrektor jaroslawskiego Progimnazjum Wojskowego.

${ }_{97}, \mathrm{O}$ Aleksandrze wiem $\mathrm{z}$ dziennikbw - pisal w polowie września 1841 r. Adam Mickiewicz do swego starszego brata Franciszka - że zostal radcą stanu i jakimś tam kawalerem. Slyszę, że się ożenił z Polką i mieszka zawsze w Charkowie"; patrz: A. Mickiewicz, Dziela t. XV: Listy, część П, Warszawa 1954, s. 377 - 378. Terajewiczowie mieszkali na Nowogrodczyźnie i byli sąsiadami Mickiewiczów. Franciszek Terajewicz, ojciec Teresy, był sędzią nowogródzkim, dzierżawił majątek Pucewicze niedaleko Zaosia. Tamże, t. XVI: Listy, częśc 
w którym w małym gronie zbierano się przy samowarze, dyskutując na tematy aktualne bądź naukowe. Marian Karol Dubiecki, który po zdaniu matury w Żytomierzu w 1856 r. wyjechał na studia do Charkowa, gdzie zamierzał poświęcić się medycynie, ostatecznie zaś trafił na Wydział Historyczno-Literacki i osobiście poznał Mickiewicza, pisał, że byl to dom, w którym: „Nie znano (...) gwaru, nie roztwierano zbyt szeroko jego podwoi, jakby w obawie, by nie wcisnęły się przez nie zbyt wielkie prądy obcej atmosfery. Na tle tego wiekuistego spokoju, co niezmiennie u progu Mickiewiczów gościł, poważnie odbijała postać gospodarza domu. W swej litewskiej długiej kapocie, z nieodstępną fajką z piórkiem $w$ ustach, siedział on pospolicie $w$ gabinecie milczący, poważny"98.

Dość częstym gościem Mickiewiczów była rodzina Karola Klaudiusza Wiszniewskiego"99. Zażyla przyjaźń łączyła Mickiewicza także z Hipolitem Siemiradzkim, mieszkającym w willi pod Charkowem ${ }^{100}$. Najczęstszym gościem Siemiradzkich „(...) bywała rodzina profesora Aleksandra Mickiewicza, który z gospodarzem domu złączony był węzłami dawnej, koleżeńskiej zażyłości, sięgającej pono epoki szkól dominikańskich, w Nowogródku jednocześnie odbywanych"101.

Nie zachowała się korespondencja między Adamem i Aleksandrem Mickiewiczami. Można raczej wątpić, czy w ogóle była. Co prawda Lipiński sugerował, że w listach Aleksandra do Adama „(...) jakie zapewne przechowały się w rodzinie znaleźć by się dał (...) niejeden ciekawy szczegół tyczący się ówczesnej kolonii polskiej w Charkowie", lecz były to tylko domysły autora ${ }^{102}$. Wrogi stosunek caratu do poety spowodował, że unikał on w zasadzie kontaktów, które mogłyby zaszkodzić jego rodzinie i przyjaciołom. Choć skarżył się na brak wiadomości od Aleksandra, to i sam do niego nie pisał aby go niepotrzebnie nie narażać ${ }^{103}$. W liście z Genewy z 12 sierpnia 1833 r. adresowanym do starszego brata Franciszka pisał: „Od Aleksandra nie mam dawno wiadomości. Pisać teraz do niego nie śmiem, żeby mu nie zrobić kłopotu" ${ }^{104}$. Z zainteresowaniem śledzil jednak karierę uniwersytecką Aleksandra. W kilka miesięcy później informował Franciszka: „Od Aleksandra nie mam wprost wiadomości, ale słyszę, że mieszka w Kijowie i że mu dobrze wiedzie się" ${ }^{105}$. Zachowana korespondencja Adama Mickiewicza potwierdza, że skomplikowane losy młodszego brata, mimo że sam poeta był także wygnańcem, nie były mu obojętne.

III, Warszawa 1955, s. 101 (list Adama do Franciszka Mickiewicza z 22 I 1847 r.). Zofia Makowiecka błędnie podaje, że Aleksander ożenił się w 1847 r. Patrz: Z. Makowiecka, Mickiewicz Julian Aleksander, op. cit., s. 706. Syn Aleksandra Franciszek rozpoczął studia w Charkowie, skąd przeniósł się na Uniwersytet Kijowski. W 1862 r. przerwał studia i powrócil do majątku ojca Gubernia pod Kobryniem (został on zakupiony przez Aleksandra Mickiewicza po opuszczeniu Charkowa) "dla zajęcia się gospodarstwem i interesami". W listopadzie $1872 \mathrm{r}$. poślubił wdowę po Traugutcie, Antoninę z Kościuszków Trauguttową. Zmarł w czasie epidemii tyfusu w lutym 1873 r. Córka Maria w 1872 r. wyszła za mąż za Święcickiego i wyjechała do Mińska. Po spłaceniu wdowy po bracie stała się właścicielką Gubernii. Mieszkała w Mińsku w domu własnym przy ulicy Podgórnej 45.

\$ M. Dubiecki, Nasze pamiqtki w Charkowie. Okruchy niedawnych wrażeń, w: "Tygodnik Ilustrowany", seria III, 1877, t. IV, ar 101, s. 338. W spomnienia Dubieckiego zamieszczone w „Tygodniku Ilustrowanym" nr 101, s. $337-338$, nr 102, s. 354 ukazały się w kilka lat później w zbiorze tegoż autora $\mathrm{Na}$ kresach $i$ za kresami. Wspomnienia i szkice, t. I, Kijów - Warszawa 1914, s. 239-253.

99 Wspomina o tym w swoim liście Maria z Mickiewiczów Święcicka (córka Aleksandra, brata Adama) do Augusta Wiszniewskiego. Patrz: Ksiega pamiatkowa na uczczenie setnej rocznicy urodzin Adama Mickiewicza (1798-1898), t. I, Warszawa 1898, s. 28-29. Wydawcy listu wspominaja, że adresat był bylym profesorem Uniwersytetu Charkowskiego, co jest błędem. Profesorem byl bowiem jego ojciec zmarły w $1863 \mathrm{r}$.

100 Oprócz willi pod Charkowem Siemiradzcy mieli także duży dom w Pieczeniegach, gdzie w 1843 r. urodzil się Henryk, wybitny malarz polski. Patrz: Slownik geograficzny Królestwa Polskiego t. I, 1880, s. 544. Pieczeniegi, początkowo sioło, później osada typu miejskiego nad Siewiernym Dońcem, $56 \mathrm{~km}$ od Charkowa, $23 \mathrm{~km}$ od Czugujewa. Patrz: PeCenigi, w: Istorija mist i sil Ukrains'koi RSR. Char'kivska oblast'. Kiiv 1967, s. $904-913$. W opisie Pieczeniegów wspomniano, że jest to ziemia rodzinna wybitnego rosyjskiego (!) malarza G. (Henryka) Siemiradzkiego, s. 913.

${ }^{101}$ M. Dubiecki, Nasze pamiqtki w Charkowie, op. cit., nr. 102 s. 354.

102 T. Lipiński, Polacy w Charkowie, op. cit, s. 80.

${ }^{103}$ A. Mickiewicz, Driela, t. XV: Listy, część II, op. cit, s. 47-48, 130, 158. W liście do Franciszka Mickiewicza z 23 III 1841 r. pisze: „O Aleksandrze nie wiem nawet, czy żyje”, tamże, s. 350.

${ }^{104}$ Tamże, s. 84.

los Tamże, s. 109. 
Niecaly rok wykladal w Charkowie profesor matematyki Grzegorz Hreczyna, absolwent Gimnazjum Krzemienieckiego, gdzie słuchał wykładów Józefa Czecha, a także i Uniwersytetu Wileńskiego, w którym poznał wybitnych uczonych pedagogów: Tomasza Życkiego, Stefana Stubielewicza i innych ${ }^{106}$. Studia uniwersyteckie ukończył w 1816 r., otrzymując stopień kandydata. W rok później został magistrem filozofii ${ }^{107}$. Mimo że egzaminy te otwierały mu droge do kariery uniwersyteckiej, nie zdecydował się na pozostanie w Wilnie. W 1819 r. zatrudniony został w Liceum Krzemienieckim jako zastępca profesora matematyki Wojciecha Jarkowskiego, dawnego swego nauczyciela ${ }^{108}$. W 1829 r. ożenił się z Michaliną Jurkowską (ur. w 1811 r.), córką znanego filologa hellenisty, profesora Liceum Krzemienieckiego, Michała Jurkowskiego ${ }^{109}$. Kozieradzki wspominał, że: „Ścisłym był w pełnieniu swego obowiązku, jak i w egzaminowaniu, bardzo zimny w obejściu się z uczniami i nie bardzo od nich lubiany. Ale człowiek bezstronny i poczciwy" ${ }^{110}$. W 1830 r. w Krzemieńcu w dwóch częściach w jednym tomie ukazały się Poczqtki algebry Hreczyny, jeden z lepszych podręczników dla szkół polskich w pierwszej połowie XIX w. ${ }^{11}$. Po zamknięciu szkoły krzemienieckiej, na wniosek kuratora kijowskiego Jegora von Bradkego, znalazł się w Uniwersytecie Św. Włodzimierza. W 1834 r. został adiunktem, a w 1837 profesorem nadzwyczajnym czystej matematyki na Wydziale Matematyczno-Fizycznym Uniwersytetu Kijowskiego ${ }^{112}$. Po obronie w 1838 r. dysertacji napisanej w języku rosyjskim Rozważania o dzialaniach kapilarnych (Razsużdenie o kapiljarnom dejstvii) otrzymał stopień doktorski. Po zamknięciu Uniwersytetu Kijowskiego przeniesiony został do Charkowa i od 19 stycznia 1840 r. objął tam już jako profesor zwyczajny Katedrę Matematyki ${ }^{113}$. W Uniwersytecie Charkowskim wykładał również mechanikę niebios na podstawie własnego rękopisu, opracowanego wedlug teorii Laplace'a ${ }^{14}$. Dla potrzeb studentów przetłumaczył Mechanike Simeona Denisa Poissona ${ }^{115}$. Zmarł nagle 20 lutego (3 marca) 1840 r. ${ }^{116}$. Zbyt krótki pobyt w Charkowie spowodował że nazwisko jego nie zostało odnotowane ani we wspomnieniach studentów, ani profesorów Uniwersytetu Charkowskiego ${ }^{117}$.

Z Krzemieńca do Kijowa, później zaś do Charkowa trafili Bonawentura Klembowski i Antoni Planson. Klembowski, uczeń Józefa Franciszka Pitschmana, wysłany dla pogłębienia znajomości malarstwa za granice, gdy po upadku powstania listopadowego powrócił na Kresy „(...) nie zastał

106 J. Bieliński, Uniwersytet Wileński, op. cit., t. II, s. 405-406. Olizar w swoich wspomnieniach nazwał Czecha „pierwszym luminarzem Krzemieńca". Patrz: G. Olizar, Pamietniki 1798-1865, z przedmowa J. Leszczyca, Lwów 1892, \&. 27.

107 J. Bieliński, Uniwersytet Wilen'ski, op. cit., t. III, s. 406.

108 A. Slowikowski, Wspomnienia szkoly krzemienieckiej, op. cit., s. 343, 348 - 349. Adam Słowikowski pisze, że w Krzemieńcu wykładal geometrię teoretyczn̨, trygonometrię płaską, geometrię praktyczną oraz algebrę. Patrz takż: M. Rolle, Ateny Wolynskie, op. cit., s. 55, 60; M. Danielewiczowa, Zycie naukowe dawnego Liceum Krzemienieckiego, op. cit., s. 72.

109 Eaustachy Iwanowski wspominał, ze był „Scisły w wykladzie i egzaminowaniu, nauczał wybornie. Bardzo zimny w stosunkach z uczniami, nigdy się nie unoszac, wzbudzał bojaźń, w życiu towarzyskim był dobry i grzeczny, ożenił się z córką profesora Jurkowskiego, piękną i dobrą osobą". Patrz: Eu... Heleniusz, Listki $z$ Ukrainy, t. III, Kraków 1902 , s. 78.

${ }^{110}$ A. Kozieradzki, Wspomnienia z lat szkolnych $1829-183$ l, op. cit., s. 143.

11 Historia nauki polskiej t. III: 1795-1862, op. cit., s. 458. Patrz także: J. Bieliński, Uniwersytet Wileński, op. cit, t. II, s. 185; M. Danielewiczowa, Zycie naukowe dawnego Liceum Krzemienieckiego, op. cit., s. 74.

112 J. Dianni, Hreczyna Grzegorz (1796-1849), w: PSB, t. X, Wrocław - Warszawa - Kraków 1962 - 1964, s. 51-52; J. Tabiš, Polacy na Uniwersytecie Kijowskim op. cit., s. 24.

11. "Zurnal Ministerstva Narodnogo Prosvešcenija" 1840, nr 3 (mart), otd. 1: rasporjażenija, s. 43.

114 F. M. S. [Franciszek Maksymilian Sobieszczański], Hreczyna Grzegorz, w: Encyklopedia powszechna Orgelbranda, t. 12, Warszawa 1863, s. 217; Biograficeskij slovar' professorov Char'kouskogo universiteta, cast' 2: Fiziko-MatematiCeskij Fakul'tet, op. cit., s. 45 -46; Grecina Grigorij Vas'ev. (1796-1840), w: Bol'Saja enciklopedija, t. 7, SPb 1896 , s. 570 .

I1s T. Lipiński, Polacy w Cahrkowie, op. cit, s. 79-80.

u6 Zurnal Ministerstva Narodnogo Prosvešðenija” 1840, ar 6 (ijun'), otd. VII: novosti i smes', s. 33.

117 Poza krótkim artykukem Ambrożego Mietlińskiego przypominającym fakty z życia $\mathrm{i}$ ważniejsze prace Hreczyny, brak o nim jakichkolwiek relacji. Patrz: A. Metlinskij, 0 tizni i trudach professora G. Grecyny, w: "Char'kovskija Gubernskija Vedomosti" 1840, nr 14: pribavlenie, s. 129-133. 
już ani liceum w Krzemieńcu, ani uniwersytetu w Wilnie" ${ }^{118}$. Prawdopodobnie w lipcu 1833 r. udał się do Kjjowa, aby objąć stanowisko nauczyciela rysunków w Uniwersytecie Sw. Włodzimierza. Poza nauczaniem malarstwa i rysunku powierzono mu także opiekę nad gabinetem dzieł sztuki znajdującym się w uniwersytecie ${ }^{119}$. W Uniwersytecie Charkowskim znalazł się w sierpniu 1839 r. i przebywal w nim do 1844 r. ${ }^{120}$ Wówczas to po uzyskaniu prawa do emerytury opuścił Charków i zamieszkał we własnym domu w Krzemieńcu. Tam też w sędziwym wieku zmarł w $1878 r^{121}$.

W latach 1839 - 1847 lektorem języka francuskiego w Charkowie był Antoni Planson, profesor gimnazjum w Świsłoczy, autor Gramatyki francuskiej wydanej w Wilnie w 1825 r. ${ }^{122}$ Po Krzemieńcu i Kijowie Uniwersytet Charkowski byl ostatnim miejscem jego zatrudnienia ${ }^{123}$. Zwolniony $z$ uniwersytetu, zamieszkał na Litwie. Zmarł w Smoleńsku 26 lipca 1873 r. ${ }^{124}$.

Lata pięćdziesiąte XIX w, stanowiące cezurę końcową artykułu, w dziejach Uniwersytetu Charkowskiego były także pewnym przełomem. Zmarło lub odeszło wielu. profesorów, dzięki którym stał się on uczelnią szeroko znaną $w$ Rosji. Jednocześnie katedry uniwersyteckie obejmowalo wówczas pokolenie, które, choć wykształcone w trudnych czasach mikołajewskich, dobrze przygotowane zostało do kontynuowania wysiłku swych poprzedników ${ }^{125}$.

11 A. Kozieradzki, Wspomnienia z lat szkolnych 1820-1831, op. cit., s. 165. Józef Bieliński pisze, że byl uczniem Jana Rustema. Patrz J. Bieliński, Uniwersytet Wilenski op. cit., t. II, s. 749.

${ }^{119}$ V. Sulgin, Istorija Universiteta Sv. Madimira SPb 1860, s. 54; M. F. Vladimirskij-Budanov, Istorija Imperatorskogo Universiteta Sv. Vadimira, op. cit, 8. 184, 191; M. Rolle, Ateny Wolyńskie op. cit., s. 251.

${ }^{20}$ E. K. Redin, Prepodavanie iskustv v Char'kovskom universitete, op. cit., s. 88.

121 Autor dwócb biogramów Klembowskiego, Janusz Derwojed, jako datę śmierci artysty podaje 1888 r., co wydaje sie błedem. Patrz: J. Derwojed, Klembowski Bonawentura (1795-1888), w: PSB, t. XII, Wroctaw - Warszawa-Kraków 1966 - 1967, s. 586-587; tenże, Klembowski Bonawentura w: Slownik artystów polskich i obcych w Polsce dzialajqcych (zmarlych przed 1966 r.), Wroclaw - Warszawa-Kraków-Gdańsk - Lódź 1986, s. 9-10. Być może daté śmierci Klembowskiego powtórzyl on za L. Janowskim. Patrz: L. Janowski, Slownik biobibliograficzny dawnego Uniwersytetu Wilenskiego, op. cit., s. 199. Tymczasem Edmund Liwski, który w rok po wyjeździe Klembowskiego z Charkowa został studentem Uniwersytetu Charkowskiego, lecz znał artyste osobiście, pisał w swym pamiętniku: „Klembowskiego, ostatniego krzemieńczanina z czasów licealnych, widziatem po raz ostatni w lipcu 1878 r. w czasie mojego wyjazdu za granice. Mial on już wtedy 85 lat (...), a w parę miesięcy później umarł, o czym dowiedziatem sie wracając z Karlsbadu w Krakowie od pani Beaupré [chodzi o Sewerynę Iwanowskq̨ Beaupré - przyp. A. K.], iony wiadomego na Syberii wygnańca"; patrz: Pamietnik Edmunda Liwskiego, Biblioteka PAN w Krakowie, rkps 6605 (strony nie numerowane). Nie ma powodu, aby nie ufać Liwskiemu. Antoni Józef Beaupré, dr medycyny, konarszczyk i zestaniec, do 1857 r. przebywał na Syberii. Patrz: M. Janik, Dzieje Polaków na Syberii, Kraków 1928, s. 97, 131, 174, 182; F. Nowiński, Polacy na Syberii Wschodniej. Zeslańscy polityczni w okresie miedzypowstaniowym, Gdańsk 1995 (wedlug indeksu). Po powrocie z zestania Beaupré zamieszkal w Krzemieńcu. Wówczas to Klembowski wykonal jego portret. Do końca życia (zmarł w 1872 r.) utrzymywał w Klembowskim przyjacielskie stosunki. Wdowa Seweryna Beaupré po śmierci męża zamieszkata w Krakowie.

${ }_{122}$ A. Kozieradzki, Wspomnienia z lat szkolnych 1820 - 1831, op. cit., s. 163. Adam Stowikowski wspomina, ze w Krzemieńcu wykładal nie tylko język, ale i literaturę francuskz. Patrz: A. Slowikowski, Wspomnienia szkoly krzemienieckiej op. cit., s. $344,355$.

${ }_{123}$ V. S. Ikonnikov, Biograficeskij slovar' professorov i prepodavatelej Imperatorshogo Universiteta Sv. hadimira op. cit., s. 553 - 554; M. F. Vladimirskij-Budanov, Istorija Imperatorskogo Universiteta Sv. Madimira op. cit, s. 123.

124 L. Janowski, Slownik biobibliograficzny dawnego Uniwersytetu Wileriskiego, op. cit, s. 339.

${ }^{125}$ R. G. Ejmontova, Professora starye i novye na rubeże 50-60-ch godov XIX v., w: Problemy istorii russkogo obscestvennogo dvizenija $i$ istoriXeskoj nauki, Moskva 1981, s. 135. 